\title{
Enrolment in Medieval English Government
}

\section{Sickness or Cure?}

In August 1834, Jules Michelet arrived in London as a senior official of the Archives royales de France, keen to observe the English way of doing things. England itself he found uninspiring: a nation of the fat and arrogant. The much-vaunted English countryside, in his opinion, was little more than a meat factory suited to a population of butchers. By contrast, England's medieval records were kept in far better conditions than those of France. At least twice Michelet visited the records in the Tower of London, meeting Henry Petrie, their chief custodian (a former dancing master), and the young Thomas Duffus Hardy. In the Tower, he viewed the serried ranks of chancery rolls in their oak presses, marvelling at the fact that the records, although stored in an eleventh-century donjon, were stored there free from damp. ${ }^{1}$

All of this in August 1834. Two months later, and in no small part in consequence of the determination to bring modern order to the cluttered memorials of England's medieval past, fire swept through what had once been England's chief archive, destroying everything in its wake. The great fire of Westminster (6 October 1834) was started when a quantity of medieval wooden tally sticks were deliberately burned as so much useless lumber. ${ }^{2}$ It might easily have destroyed not just the tally sticks but the vast majority of England's medieval records. Indeed, had the chancery and exchequer rolls still been stored at Westminster, as the financial archives of France's kings were still stored in the chambre de comptes in 1737, we might today know as little of enrolment in medieval England as we do, say, of the great series of Scottish chancery and exchequer rolls, lost at sea in 1660 when the ship carrying them back to Edinburgh (from where they had been removed a decade earlier by Oliver Cromwell) went down with no cargo saved. ${ }^{3}$ We might know even less of English enrolment than we do today of the exchequer and chancery rolls of Ireland, in theory totally destroyed in the explosion that ripped through the Dublin Four Courts in 1922, in reality not so entirely

1 Michelet, Journal, ed. Viallaneix, 123-160, esp.128, 154 (visits to the Tower), 131 (English countryside).

2 Shenton 2012.

3 Thomson 1922, esp.15-16, noting, by contrast, the survival of virtually all manuscript books, more than a thousand of which had already been returned to Edinburgh in 1657. For the survival of copies of various of the lost rolls, made by the antiquary Thomas Hamilton, see Taylor 2016, 351-354.

For their assistance with what follows, I am especially indebted to Richard Cassidy, Adam Chambers, Sean Cunningham and Frédérique Lachaud.

Ә Open Access. () 2019 Nicholas Vincent, published by De Gruyter. (c) BY-NC-ND This work is licensed under the Creative Commons Attribution-NonCommercial-NoDerivatives 4.0 License.

https://doi.org/10.1515/9783110645125-005 
lost as was once supposed..$^{4}$ Not only this, but had the English rolls been burned in 1834 , it is doubtful whether any historian today would credit their true quantity or extent. $^{5}$

Instead, although a large part of the archive of Parliament was burned in 1834, the rolls themselves survived. This was a welcome, some might think a miraculous deliverance. But it was also a reflection not so much of the perceived significance of the rolls as of their redundancy. Precisely because they were no longer required for the day-to-day functioning of government, as early as the 1270s, the early chancery rolls had gradually been transferred, away from the chancery at Westminster to gloomier incarceration, first in the Temple, later in the Tower of London. ${ }^{6}$ Of the greater series of medieval enrolments originally stored at Westminster, the pipe rolls had been moved first to Gray's Inn (c.1715), then (in 1793) to even more squalid neglect in the vaults of Somerset House. ${ }^{7}$ Chancery rolls earlier than the reign of Richard III were kept at the Tower, but anything later than this remained scattered in promiscuous confusion across the Rolls Chapel and Rolls House in Chancery Lane. ${ }^{8}$ Into the 1830s, it was reported, so dark was the place in which various of the patent rolls were stored that individual rolls could be located "only by guess matured into habit" (still, in many instances, the best means of locating a great deal of material, albeit now rather better catalogued, in the National Archives at Kew). ${ }^{9}$ The medieval court rolls were even more widely dispersed. As late as the 1850s, a historian seeking to follow the sort of lead today easily traced in an hour or so at Kew, would instead have been obliged to travel backwards and forwards between half a dozen different London offices, frustrated at every turn by exorbitant fees, surly or incompetent custodians and the sheer chaos in which so many of the rolls were stored. ${ }^{10}$ Even the early chancery rolls, whose state of preservation so impressed Michelet, remained both difficult to manipulate

4 Crooks 2013, with further details online at https://chancery.tcd.ie/content/irish-chancery-rolls\# structure-and-form-of-the-irish-chancery-rolls (last accessed: 31.7.18). For what little survives of the Irish pipe rolls, otherwise destroyed in 1922, see the fragment of the roll, probably of 46 or 47 Henry III (1261-1262 or 1262-1263), preserved as London, BL, Add. Ch. 26515. Another fragment, from an original now lost, apparently from the roll 45 Henry III (1260-1261), is reproduced in Facsimiles of National Manuscripts of Ireland, ed. Gilbert, vol.2, no.73. Rather more survives of the Irish judicial records, including an entire original eyre roll of the year 8 Edward II in 103 membranes (Dublin, NAI, KB 1/1) and a rather more fragmentary bench roll (KB $1 / 2$, today disbound and severely cropped).

5 See here Vincent 2009, xvi-xvii, suggesting that had Domesday Book not survived, it too would be assumed to be a figment of the antiquarian imagination.

6 For the transfer of chancery rolls to the Temple in November 1267, but with clear expectation that they could be searched there or recalled to chancery, see Close Rolls 1264-8, 407. Thereafter, see Maxwell-Lyte 1926, 400-401; Wilkinson 1929, 54, 59-64.

7 Stenton 1952, 282-283, 286-290.

8 Wernham 1956, esp.17-18.

9 Wernham 1956, 27.

10 For exorbitant search fees, see Stenton 1952, 283, 287-288. For general chaos, Jenkinson 1949, 8, noting in particular the fate of the ancient miscellanea of the king's remembrancer, removed from 
and expensive to use. Theirs was a story as much of neglect and sinecurism as of careful archival custodianship. It was nonetheless a story that suggests that the rolls themselves had become symbolic of the medieval origins of the modern British state. As early as the 1270s, six centuries before their neglect provoked the 1838 Public Record Office Act, they were already both a tool of government and one of government's most immediately recognizable icons.

I have written of the rolls, their origins and their making, in a number of contexts, and I do not propose here merely to rehearse ideas that I have expressed elsewhere. ${ }^{11}$ Instead, I shall address a rather different set of questions, in particular seeking to understand the evolution of the parchment roll in England in its symbolic rather than its practical administrative guise. The key here must be to divorce the administrative history of the medieval state (the province of Thomas F. Tout, Joseph Strayer, or Robert-Henri Bautier) from the diplomatic realities of parchment and ink from which the rolls themselves were fashioned. Too often, the written records of medieval government have been treated not as a body of evidence in their own right, but merely as a stepping stone towards the processes by which government itself functioned. Duly edited and indexed as books, such records offer a feast for the historians of administration, not least for the access they allow to the career details of many thousands of individual medieval administrators. By contrast, in which follows I shall be chiefly concerned with artefacts rather than with processes, with parchment rather than people. ${ }^{12}$

Long before Michelet visited the Tower, indeed from the very earliest occasion when a member of the king's administration set out to describe the functioning of English government, the form of the parchment roll had already achieved iconic status. There is thus hardly a page of the printed edition of Richard fitz Nigel's Dialogue of the Exchequer (c. 1178) from which the word rotulus is absent. This is hardly surprisingly in a treatise whose avowed intent was to explain the making of the exchequer pipe roll. What later centuries came to know as the 'pipe roll' was referred to by Richard himself as the "great" roll, the "annual" roll, or more often simply the "annal". ${ }^{13}$ Even so, in Richard's day its writing and calculations already involved considerable efforts not just at the exchequer but in most other departments of English government. Thirty years later, by which time not only the exchequer but the chancery had embarked on

\footnotetext{
Westminster Hall in 1830 to the King's Mews at Charing Cross (now Trafalgar Square), there to become "a mass of putrid filth, stench, dirt and decomposition".

11 See in particular here Vincent 2004, 2017; Vincent (forthcoming a and forthcoming b).

12 For access to the rolls themselves, there are invaluable images of long runs of many of the principal series of English enrolment at Robert Palmer's Anglo-American Legal Tradition website, sponsored by the University of Houston Law Center: Palmer/Palmer/Jenks (s. d.).

13 See Dialogus de Scaccario, eds. Amt and Church, for the pipe roll(s) as the magnus rotulus (106), magnus annalis rotulus $(110,118,128)$, annuali rotuli $(100)$, annalis rotulus $(110,124)$, magni annales compotorum rotuli (94), or merely as the annalis $(140,142,146,152,156,172,186)$.
} 
a major programme of enrolment, we find a similar identification between rolls and the outward panoply of government, in the so-called Planctus super episcopis: a satire directed against the courtier bishops of King John, including Peter des Roches, bishop of Winchester, "the warrior of Winchester, up at the exchequer [...] turning the king's roll". ${ }^{14}$ By this time too, the vocabulary of enrolment was already richly developed, spawning not merely a host of references to rotulus and rotuli, but now shading into verbs and gerunds: irrotulare, irrotulamentum, irrotulatio, and in due course a host of ablative absolutes or references to "searches of the rolls": inspectis [...] scriptis et irrotulationibus, visis et scrutatis rotulis, quarantur rotuli, vocauit rotulos [...] ad warantum, and so forth. ${ }^{15}$ As testimony to this fixation with the rotulus, from the twelfth century onwards, we already find the most famous of the treasury's written memorials misidentified not as a book but as a roll. Domesday Book thus became generally, albeit falsely, known as "the roll of Winchester". ${ }^{16}$ No doubt because of the persistent assumption that English government was an administration conducted per rotulum, this was a terminology that stuck. Into the eighteenth century, the greatest of modern authorities on the medieval exchequer, Thomas Madox, continued to refer to Domesday not as a book but as a "rent roll" or rotulus censualis. ${ }^{17}$

Like Michelet, 130 years later, Madox in the early years of the eighteenth century was able to survey the rolls not simply one-by-one, so that he might enquire after particular historical details, but as a visual spectacle, arranged in sequence from the twelfth-century onwards. A woodcut image of the great oak presses in which the pipe rolls were stored in the Pipe Office at Westminster, cupboard by cupboard and shelf by shelf, accompanied Madox's written description of their arrangement first published in 1711, here referring to the cupboards, numbered from right to left, as capsae and each of their shelves as an abacus (fig. 1). ${ }^{18}$ To assume, however, that the rolls were deliberately displayed in this way, as a symbol of English government, is to confuse the privileged access permitted to Madox, Michelet and a small band of semi-professional historians, with what a wider public was allowed to see of the medieval English

14 Wright 1839, 10: Wintoniensis armiger presidet ad scaccarium [...] regis revolvens rotulum.

15 For a host of instances here, see Ashdown/Howlett/Latham 2018, 1484-1485, here also citing Curia Regis Rolls 1922-2006, vol. 2, 299; vol. 5, 164-165.

16 For early instances here, see Clanchy 2013³, 138-139, and cf. also Curia Regis Rolls 1922-2006, vol.1, 263 (Robertus <camerarius> ponit se super rotulum Wintonie quod terra illa pertinet a conquestu Anglie ad feudum quod ipse habet, 1200). Round 1909³ 215 , long ago questioned whether various of these references to the rotuli Wyncestr' (sometimes in the plural), refer to Domesday or some other set of records of hidage, earlier than the 1160s.

17 Madox 1769², vol. 2, 456 (Disceptatio Epistolaris): post Rotulum Censualem quem Librum Domesday vocant, perhaps here influenced by the idea of the master exactory roll (the rotulus qui exactorius dicitur quem quidem nominant breue de firmis or rotulus exactorium) that, according to the Dialogus (Dialogus de Scaccario, eds. Amt and Church, 94, 188), was stored together with Domesday (here the Liber Iudiciarius) and determined many of the annual charges entered on the pipe roll.

18 Madox 1769², vol. 2, 455, 457: Disceptatio Epistolaris. 
state. It is surely instructive that, in Madox's day, the rolls were displayed from right to left, reversing what we might consider a linear progression from the past into the present. Not only this, but for more than a century after Madox's description of the wooden cupboards in the Pipe Office, $c$. 1711, we have no visual record of the archival arrangements either of the chancery rolls at the Tower or of the pipe rolls in their various migrations from Westminster via Holborn to Somerset House. By the time we next catch sight of them visually, in a photograph perhaps of the early twentieth century, the earliest chancery rolls had long been retired from public view, locked away in a special 'Rolls Room' (built 1877) of the new Public Record Office in Chancery Lane (itself built 1851-1857). ${ }^{19}$ Those using the search rooms at Chancery Lane, especially the splendidly-appointed new Round Room (begun 1863), were permitted to order up the rolls for consultation, one by one. ${ }^{20} \mathrm{~A}$ special 'pipe roll stand' was constructed as a frame from which the bulkier rolls could be hung and read. ${ }^{21}$ After 1902, visitors might inspect the Record Office's new museum, built on the site of what had formerly been the Rolls Chapel, itself part of the Domus Conversorum (1232) that, by the 1260s, was already colonized by clerks of the royal chancery. ${ }^{22}$ In the Museum, they could view such iconic objects as Domesday, a sequence of original royal charters, the statute roll 11 Henry VII (1495), and several sixteenth-century king's bench plea rolls, presumably selected as those least likely to be ordered for use by readers (fig. 2). ${ }^{23}$ No attempt, however, was made to display the full abundance of the rolls, even to those enterprising enough to visit or work in the Public Record Office. The Round Room, it is true, was abundantly furnished with shelves, reaching high up into its glass dome. But these were used to store books, especially calendars and indexes and, in the less accessible upper levels, the more redundant but visually attractive of uniformly bound codices. ${ }^{24}$ From 1877 through to the Round Room's closure 120 years later, the intention was to display impressive lumber, not in any way to transform the medieval rolls into a spectacle of antiquity.

19 Cantwell 1991, 269 and plate 33, from Kew, TNA, PRO 50/59, no. 76, apparently with electric rather than gas lighting.

20 For the building of the Round Room, Cantwell 1991, 208-209, 225, and for images Cox et al. 1988, viii; Kew, TNA, PRO 50/59, nos.77-78. As suggested by Hallam 1990, 40, almost certainly modelled on Sydney Smirke's domed reading room at the British Museum (1854-1857).

21 Image as the backcover to Cox et al. 1988, showing the stand in use by Norman Evans.

22 For the migration of chancery officials to the Domus as early as the 1260s, see Vincent (forthcoming b), focusing in particular on the chancery clerk Adam of Chesterton.

23 For the conversion of Chapel into Museum, see Cantwell 1991, 338-343. For its contents, see Maxwell-Lyte $1902^{4}$; Cox et al. 1988, 22-25. For an early photograph of Domesday and Little Domesday displayed, apparently with no protection other than an attendant, see Kew, TNA, PRO 50/59, nos. 47, 51, and for the display of rolls and charters, nos.57-63, 71

24 David Crook, whose memory of the Round Room extends back to the 1970s, suggests that the books so displayed were either the 2,000 or more volumes of king's bench judgment books (Kew, TNA, J 20), or possibly the 2,934 volumes of chancery division cause books (Kew, TNA, J 12) 


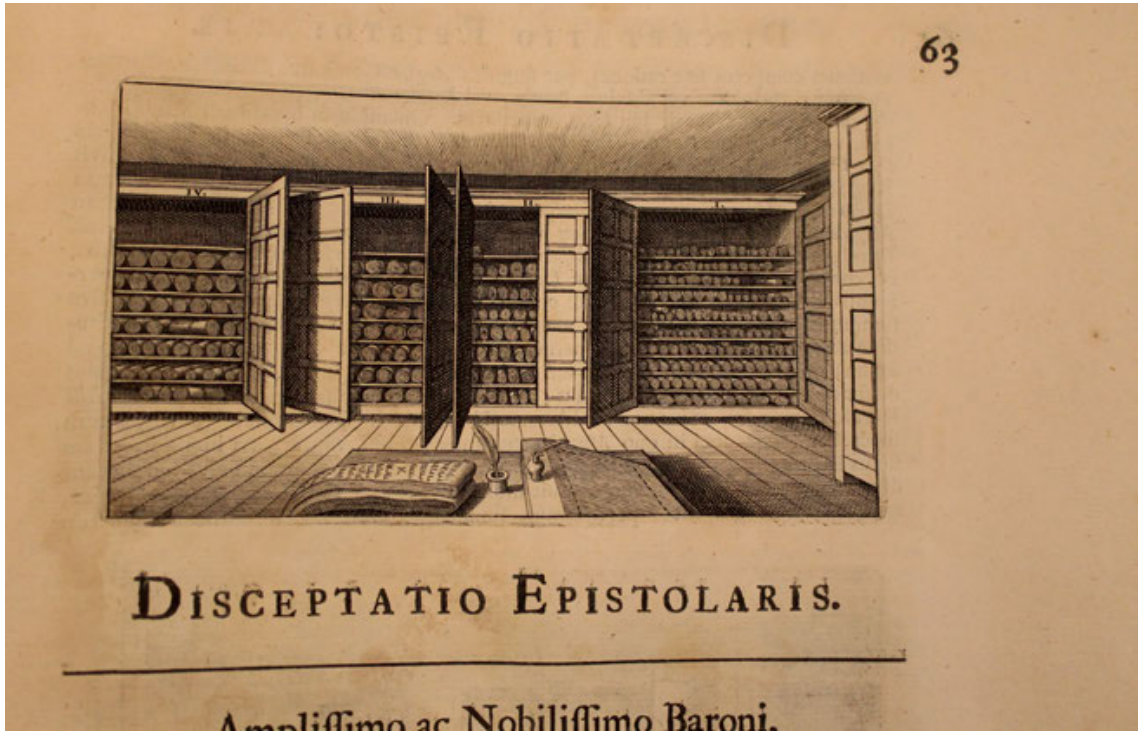

Fig. 1: Madox' woodcut illustration of the Pipe Office at Westminster (cf. Madox 1711¹, 63).

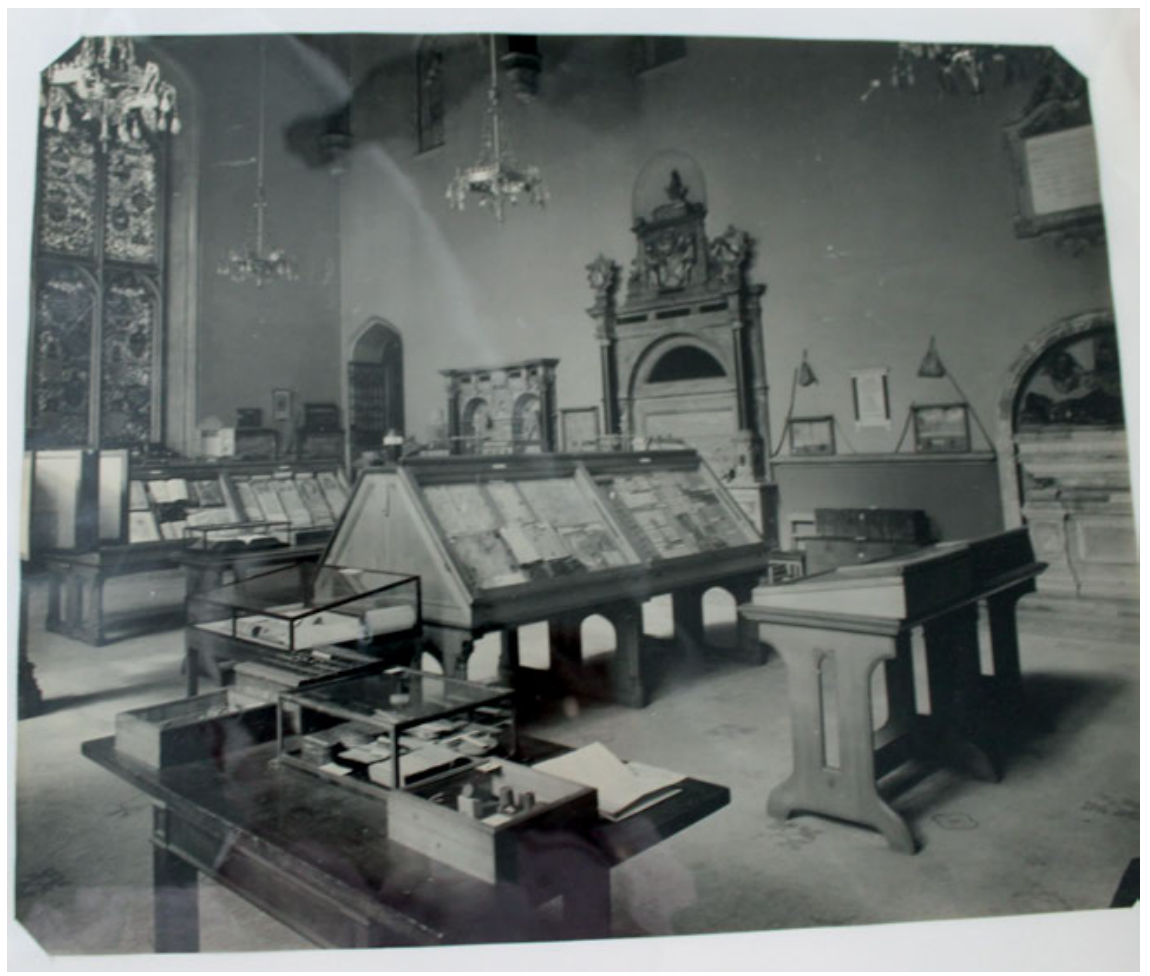

Fig. 2: Display in the Public Record Office Museum, c.1910. 
In this, the rolls' custodians in the nineteenth and twentieth centuries merely followed medieval precedent. For a privileged few, most notably the officials of exchequer and chancery, and the sheriffs and others who attended at Westminster each year to render their accounts, the rolls were both a visual and a physical reminder of royal authority from at least the twelfth century onwards. To the vast majority of the king's subjects, however, with little or no idea of the rolls' contents or extent, they remained an invisible albeit symbolic resource. Our most detailed images of medieval Westminster at work-the so-called Whaddon Hall drawings (c.1450), today preserved in the library of the Inner Temple-show us teams of clerks in the exchequer, the chancery and the law courts, scribbling onto long individual parchment sheets; even swathes of writs in chancery in the process of being sealed, but not a single true roll (fig. 3). ${ }^{25}$ This, only a few decades after the 'Great Rumour' of 1377, in which the peasants of forty of more manors across southern England had proclaimed entirely specious expectations of the king's archives, believing that thanks to that mysterious thing, Domesday alias “The King's Book” or “The Book of Winchester”, all labour services not mentioned in "The Book" were about to be abolished. ${ }^{26}$ For royal officials and for a lucky few antiquaries, able to charm or bribe their way into the repositories in the Tower and elsewhere, from the sixteenth century the rolls became a significant store of historical knowledge. Even so, they remained a resource chiefly intended for the defence of royal rather than private right. They were thus accessible to the king's critics or to those in search of 'constitutional' precedents only under sufferance and the threat of draconian prosecution for anybody (most famously William Prynne) deploying historical records against the perceived interests of the crown. ${ }^{27}$ This combined with their significance to a small army of sinecure holders, responsible for their upkeep and preservation, rendered them far from easy of access. With the exception of primitive attempts at listings, the earliest of them printed in 1631, no reliable inventory to any individual set of rolls was published before 1772 and Joseph Ayloffe's Calendars of Ancient Charters. ${ }^{28}$ This very briefly summarized the principal series of enrolments, with an appendix of item-by-item listings of contents for the cartae antiquae, Welsh

25 Corner 1864, with better modern facsimiles, printed in Langbein/Lerner/Smith 2009, 277, and online at https://www.innertemplelibrary.org.uk/collections/manuscript-collection/four-illuminatedmanuscripts/ (last accessed: 3.8.18).

26 Faith 1984.

27 For Prynne, see Lamont 1963, 1996. More generally, for an introduction to the polemical uses of the records in the Tower, see, for example, Douglas 1951²; Styles 1956; Sharpe 1979, and most famously Pocock $1987^{2}$.

28 Powell 1622, heavily revised with the assistance of lists of individual rolls supplied by Agarde/Powell 1631, esp. 145-210, at 146-166, listing 66 charter, fine, close and patent rolls of the reign of John, and 300 of the reign of Henry III. For Agarde's inventory of exchequer records, see The Antient Kalendars and Inventories of the Treasury of His Majesty's Exchequer, ed. Palgrave, vol.2, 311-335. Agarde and Powell's 1631 guide (8-9) also for the first time properly noticed the charter and cartae antiquae rolls at the Tower, at 11 recording the standard Tower search fee as $10 \mathrm{~s}$. 


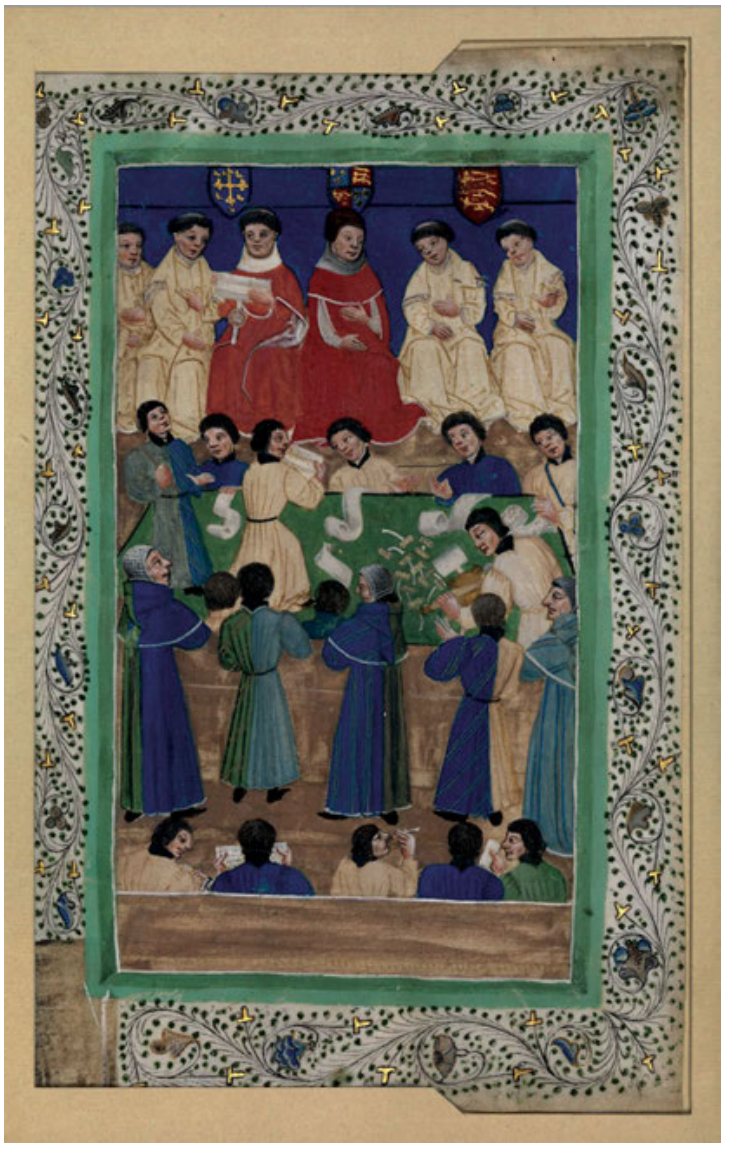

Fig. 3: Whaddon Hall drawing of the court of chancery.

and Scotch rolls. ${ }^{29}$ For the vast majority of the king's subjects, meanwhile, the rolls remained inaccessible: symbolically powerful yet essentially mysterious.

Into the nineteenth century, and save for what circulated in manuscript copy amongst earlier antiquaries, the actual contents of the rolls remained unpublished. Selective extracts could be found in the work of such authorities as Prynne, Madox or Thomas Rymer. In search of monastic evidences, Roger Dodsworth, Sir William Dugdale, and in due course Thomas Tanner, all scoured the rolls, in Tanner's case publishing detailed listings of information scattered across a great variety of rolls of the chancery and the exchequer. ${ }^{30}$ Even so, and despite the publication of the parliament rolls (in six volumes, 1767-1777, followed by an index in 1832) and Abraham Farley's edition of Domesday Book (1783, with indexes and additamenta in 1816), by 1800 not a single roll from the main series of chancery or exchequer enrolments had

29 Ayloffe 1772.

30 Tanner $1744^{2}$. 
been published in extenso. Even the Record Commission of 1801, intended to make good the shameful neglect of rolls and records, contented itself with the publication of calendars and extracts, for the most part woefully unreliable. ${ }^{31}$ The only series of enrolments that the first Record Commissioners made any attempt to tackle in extenso, were either peripheral (the so-called hundred and Scotch rolls), or virtually useless as evidence for the chief thrust of English medieval government (as was the case with random excerpts from the originalia rolls, published between 1805 and 1810). ${ }^{32}$ By 1830, indeed, the main series of English chancery rolls had been worse served than either the Scotch rolls (published in extenso between 1814 and 1819) or the Irish patent and close rolls preserved in Dublin Castle, calendared in 1828 by Edward Tresham (poorly, but even so with greater competence than had been displayed in dealing with their English equivalents). ${ }^{33}$ No roll from the principal series of English chancery or exchequer enrolments was published in extenso until 1833, when (under the auspices of the new 1831 Record Commission) there appeared not only the first volume of Thomas Duffus Hardy's edition of the close rolls of the reign of King John and Henry III but also Joseph Hunter's editions of the pipe roll 31 Henry I and the chancellor's roll 3 John. ${ }^{34}$ Even then, the collapse of the 1831 Record Commission ensured that, after barely a decade carrying publication of charter, patent and close rolls to the end of the reign of King John, in the forty years after 1844 no further volumes were added to the tally achieved by Hardy and Hunter. ${ }^{35}$

The subsequent decision to focus on chronicles and other "memorials of Great Britain and Ireland during the Middle Ages”, a venture directed after 1857 from the

\footnotetext{
31 Most notably in Calendarium rotulorum chartarum et inquisitionum ad quod damnum 1803 (offering virtually nothing save a list of beneficiaries, and even then inaccurately), and Calendarium rotulorum patentium in turri Londoninensi 1802 (from Astle's handwritten abstracts of 1775, a little better than the equivalent 1803 calendar of charter rolls). Superior to these, though even then far from ideal, were the excerpts from plea rolls published as Placitorum in domo capitulari Westmonasteriensi asservatorum abbreviatio 1811, and Placita de quo warranto temporibus Edw. I. II. \& III. in curia receptae scaccarij Westm. asservata 1818.

32 Rotuli Hundredorum 1812-1818 (from Kew, TNA, SC 5/1-366); Rotuli Scotiae in turri Londinensi et in domo capitulari Westmonasteriensi asservati 1814-1819 (from Kew, TNA, C 71/1-113); Rotuli originalium in curia scaccarii abbreviatio 1805-1810 (from the medieval parts of the series now Kew, TNA, E 371/1-1102).

33 Rotulorum Patentium et Clausorum cancellariae Hiberniae calendarium 1828, and cf. the extensive extracts from Irish records, prepared in 1829-1830 in full Latin transcript, eventually published as Chartae, Privilegia et Immunitates 1889.

34 Rotuli litterarum clausarum in turri Londinensi asservati, ed. Hardy; Magnum Rotulum Scaccarii vel magnum rotulum pipae de anno tricesimo-primo regni Henrici primi, ed. Hunter; Rotulus cancellarii, vel antigraphum magni rotuli pipae, de tertio anno regni regis Johannis, ed. Hunter.

35 Most notably with Hardy's editions of patent rolls 1835 and charter rolls Rotuli chartarum in turri Londinensi asservati, ed. Hardy, and his second volume of the close and patent rolls Rotuli litterarum clausarum in turri Londinensi asservati, ed. Hardy, this latter extending to 1227 , the other series all ending with King John's death in 1216.
} 
new Public Record Office by commission from the Master of the Rolls, led to a series of 250 still highly useful published volumes. ${ }^{36}$ But in these hardly a single medieval 'roll' was consulted let alone newly edited. The only exception here, an enrolment of proceedings in council during Richard II's Irish expedition of 1392-1393, was published not from any English public record but from a manuscript then in private ownership at Kilkenny Castle, today preserved in the National Library of Ireland. ${ }^{37}$ We are thus confronted by the irony that the much-feted 'Rolls Series' was published with virtually no regard for the chancery rolls from which its name derived. Not until 1891, and then, to begin with, only in inadequate calendared versions, did the Public Record Office make any serious attempt to repair such neglect. ${ }^{38}$ Meanwhile, it was left to private enterprise, first by the Pipe Roll Society established in 1883, thereafter by the Frenchmen, Francisque Michel and Charles Bémont, to attempt what the Record Office was yet too timid to venture: full Latin editions of the earliest surviving chancery and exchequer rolls. ${ }^{39}$ However iconic of medieval English government they may have become, into the 1880s the rolls themselves derived their reputation more from hearsay than from any attempt at public display or scholarly edition.

Why this reluctance to engage with the physical realities as opposed to the symbolic mystique of the rolls? The answer clearly resides in stupefaction induced by the sheer quantity of materials that by the 1830s had accumulated in a dozen or more record repositories across Westminster and London. Statistics here remain impressionistic but nonetheless staggering. If we take merely the three principal series of chancery enrolments, we find that the National Archives at Kew today house 200 charter rolls, 5,886 patent rolls and more than 20,900 close rolls, all preserving many hundreds, in some cases many thousands, of royal letters dispatched from the king or his chief writing office. ${ }^{40}$ This before ever we approach the foothills of fine, liberate, cartae antiquae, Gascon, Norman or other chancery rolls, let alone the twin peaks of exchequer or judicial enrolments (pipe, chancellors', memoranda, curia regis, bench and eyre rolls, as well as vast heaps of miscellaneous enrolled materials, not least

36 The best introduction here remains that by Knowles 1963.

37 A Roll of the Proceedings of the King's Council in Ireland, ed. Graves, today Dublin, NLI, MS 2556/1, where it is less than perfectly preserved, heavily galled by its editor, dismantled from its original 'chancery' format, with each membrane now cut in two in order to bind them into a codex. See also, at the very end of the series, Maitland 1893, but for the most part merely reprinting enrolled materials long available in Rotuli parliamentorum: ut et petitiones in parliament, eds. Strachey et al.

38 The series of such calendars begins with Edward III (CPR 1891-1914), with prospectus noting interim efforts at vol.1, v-xi, continuing thereafter with Edward I (CPR 1893-1901).

39 For the Pipe Roll Society, whose first three volumes, comprising editions of the pipe rolls 5-6 Henry II and a general introduction, appeared in 1884, see Stenton 1952, 292. For the Gascon rolls, see Rôles Gascons, eds. Michel and Bémont.

40 Kew, TNA, C 53 (charter rolls); C 66 (patent rolls); C 57 (patent rolls supplementary); C 54/1-20898 (close rolls, main series), supplemented in the case of the close rolls by the very earliest, now C 62/1-3, and the distinct series of C 55/1-19 (close rolls supplementary). 
those of the exchequer of pleas). By 1880, even from the three principal chancery series, a mere 17 charter rolls, 16 patent rolls and 37 close rolls had been competently edited or calendared; from the exchequer side, a mere five (of the surviving 672) pipe and a single example (of the surviving 612) chancellors' rolls. For some idea of scale here, let us consider the 20,850 close rolls that in 1880 remained unedited. Even allowing an average length to these rolls of 10 metres (and most, unrolled, would far exceed that), we are dealing with a length of parchment that would stretch more than 200 kilometres: roughly the distance from Cardiff to London, or for those who prefer such things in German perspective, allowing just this one series amongst many others to be unfurled from Heidelberg all the way to Mannheim and back, not once but six times! ${ }^{41}$

Statistics, of course, are easily distorted. Because many series of enrolment were begun in the Middle Ages but continued, as a result of tradition and sinecurism, through to the 1830s (in the case of the patent rolls even through to the present day), only a proportion of the enrolled material now preserved in Kew is truly medieval. If we place our cut-off point here at the end of the reign of Richard III in 1485, this would allow us to include virtually all of the 200 charter rolls, but only 615 of the 5,886 patent rolls and an even smaller proportion, 360 out of nearly 21,000 close rolls. ${ }^{42}$ The close rolls are the chief distorting element here. Elsewhere, if we turn to the enrolments of exchequer and judiciary, we find that slightly more than a third of the principal exchequer rolls, and slightly less than half of the judicial rolls are medieval. ${ }^{43}$ In three brief tables below (tab.1-3 in the Appendix), I have set out lists of various more significant classes of enrolment from the chancery, the exchequer and the judiciary. The 31 series listed here make up only a proportion of those begun in the Middle Ages. Even from these 31 series, however, we find a total of more than 46,000 rolls. Of these, nearly 10,000 date from the medieval period, before 1486. As early as the reign of Richard II, when our earliest proper inventories survive, the chancery rolls already formed a substantial collection. Even if we include here only those documents reported as belonging to the first century of enrolment, through to the end of the reign of Henry III (1216-1272), by 1381 the chancery was already responsible for two sacks containing 378 charter, patent, fine, close and liberate rolls of the reigns of John and Henry III, together with 16 bundles from the same reigns relating to escheats and a five further sacks of miscellaneous early memoranda. ${ }^{44}$ Long before this, indeed as early as the reign of King John, the chancery rolls had acquired their own specified keeper. This

\footnotetext{
41 As a sample, the penultimate roll in the main series, Kew, TNA, C 54/20897 (close roll 2 Edward VII part 36), is written on 38 membranes of parchment each approximately 60 centimetres long, making for a total length of just under 23 metres, or 75 feet!

42 Kew, TNA, C 53 (charter rolls), nos. 1-198 (excluding 2 rolls for the reign of Henry VII and the first 8 years of Henry VIII); C 66 (patent rolls), nos. 1-560, and from the supplementary series C 67/1-53 and 94-96; C 54 (close rolls), nos. 1-338, together with those displaced as C 62/1-3 and C 55/1-19.

43 See appendix below.

44 List of Chancery Rolls 1908, iv, from Kew, TNA, C 47/34/19 (Inventory of September 1381).
} 
was an office originally without title, but by the 1260 s already being designated as that of the custos rotulorum, subsequently "Master of the Rolls". ${ }^{45}$

For present purposes what matters here is not just the sheer number of the rolls but the abundance of their individual contents. After their beginnings in the reign of King John, the only set of close rolls to date edited in full Latin transcript are those of the reign of Henry III. Published over a period of 142 years, between 1833 and 1975, these today occupy 7,317 pages of octavo and 577 pages of double-columned folio print. These in turn are supplied with a further 1,761 pages of indexes, principally to persons and places, making for a total of more than 9,000 pages, more than 4.5 million words, occupying approximately 80 centimetres ( $2 \mathrm{ft} 7 \mathrm{in}$ ) of shelf-space. ${ }^{46}$ From the exchequer and judicial sides, even after more than 180 years of endeavour and more than 100 increasingly bulky volumes (occupying nearly four metres, or 14 feet of shelfspace), the publication of pipe and chancellors' rolls has reached no further than 1224; that of bench and curia regis rolls, in more than 20 volumes, no further than $1251 .{ }^{47}$ The publication of memoranda rolls lags even further behind, with only four such rolls as yet printed either in extenso or calendar, even of the 95 that survive to the end of the reign of Henry III, let alone of the more than 500 surviving before $1486 .{ }^{48}$ Taken altogether, and although in many cases printed merely in abbreviated calendar form, the modern editions of charter, patent, close, fine, liberate, Gascon, treaty, curia regis, pipe and exchequer memoranda rolls for the single reign of Henry III (1216-1272) are

45 For the emergence of this office, from 1215 onwards, see Vincent (forthcoming b), noting in particular Rotuli litterarum clausarum in turri Londinensi asservati, ed. Hardy, vol.1, 196b; Rotuli litterarum patentium in turri Londinensi asservati, ed. Hardy, 137b; CLR (1916-1964), vol. 6, no. 2376 (1263); Hanworth 1935; Sainty 1993, 145.

46 Rotuli litterarum clausarum in turri Londinensi asservati, ed. Hardy, vol.1, 293-655, vol.2; Close Rolls of the Reign of Henry III 1902-1938; Close Rolls of the Reign of Henry III, ed. Morton.

47 For details here, see Mullins 1958-1983, vol.1, 232-238, vol.2, 83-88, and http://www.medieval genealogy.org.uk/sources/pipe.shtml (last accessed: 5.8.18), the publication of exchequer records today having reached as far as the pipe roll for 8 Henry III (The Great Roll of the Pipe for the Eighth Year of the Reign of King Henry III [Michaelmas 1224], ed. Amt), with thereafter isolated editions of the pipe rolls 14 and 26 Henry III: The Great Roll of the Pipe for the Fourteenth Year of the Reign of King Henry the Third, Michaelmas 1230, ed. Robinson; and The Great Roll of the Pipe for the 26th Year of the Reign of King Henry III, A. D. 1241-1242, ed. Cannon. The Curia Regis Rolls 1922-2006 continued a tradition of publication first established for the reigns of Richard I and John in Rotuli curiae regis, ed. Palgrave, and cf. http://discovery.nationalarchives.gov.uk/details/r/C10030 (last accessed: 5.8.18).

48 The Memoranda Roll for the Michaelmas Term of the First Year of the Reign of King John (11991200), ed. Richardson; The Memoranda Roll for the Tenth Year of the Reign of King John (1207-8), ed. Brown; Memoranda Rolls Preserved in the Public Record Office, ed. Brown. The two earliest Lord Treasurer's Remembrancer rolls (for the years 1 and 10 John) survive as Kew, TNA, E 370/1/3-4. Thereafter, see Kew, TNA, E 159/1-261 (King's Remembrancer memoranda rolls, ranging in date from 1217 to 1485), of which E 159/1-47 are of the reign of Henry III; E 368/1-258 (Lord Treasurer's Remembrancer rolls, of the same date range), of which E 368/1-46 are of the reign of Henry III. Thereafter, of the later rolls, only an isolated pair, covering the final year of Edward II's reign, are published in calendar form as Latham 1968. 
sufficient in themselves to fill a decent-sized bookcase, occupying shelf-space that, for French or German comparison, would take half a dozen sets of the published five volumes of the Layettes de trésor des chartes, or an entire set of the Monumenta Germaniae Historica Scriptores.

As these figures suggest, although not generally presented as a visual spectacle, the rolls achieved their iconic status through a combination of antiquity and sheer bulk. Part of their power, of course, derived from the perception that they were not only ancient but fully comprehensive, responding to the same all-consuming thirst for information that had the royal survey of 1086, to be known as 'Domesday', even before its chief product, originally called “The King's Book”, was renamed as the Liber Iudiciarius, or in the English vernacular "Domesday Book". ${ }^{49}$ This, as the peasants of the 1377 'Great Rumour' were to discover, was to over-estimate the true extent of the archives. As I have suggested elsewhere, wide swathes of English medieval government were never fully reported in the chancery enrolments, not least the more secret or diplomatically sensitive of royal correspondence. In the same way, the pipe rolls and records of the exchequer provide a year-by-year snapshot of royal finance, yet tend to omit many of the features that a modern historian might be most anxious to probe: how much money did the king actually receive and spend; what were the profits of war; what the real costs of his armies, his buildings, or his court establishment? ${ }^{50}$ Even so, and despite these caveats, the sheer extent of the rolls in itself constitutes one of their more impressive features, obvious both to contemporaries and to subsequent enquirers. Why, though, this bulk? Why, in particular, did England take the turn towards laborious and repetitive enrolment of many tens of thousands of routine instructions and processes that in other medieval polities-in France, or at the papal court, for instance-were smoothed away by the decision to register selectively rather than in extravagant and ultimately futile abundance?

Various suggestions have been offered here. One lies in the paranoia of King John, the chancery rolls' first patron: a ruler, it has been argued, so determined to keep his finger on the administrative pulse that he commanded the copying of all his outgoing letters, from the most significant to the entirely trivial. ${ }^{51}$ Another explanation might lie in the desire by royal government to lay claim to a degree of that same divine omniscience vested in the angels, frequently depicted with scrolls intended for use in God's Final Judgment of mankind. Here, indeed, the form of the rolls may deliberately reflect an association between enrolment and eschatology stretching back via Domes-

49 Herefordshire Domesday, circa 1160-1170, eds. Galbraith and Tait, xxiv-xxviii, xxx; Hallam 1986, 32-51; and most recently Harvey 2016. See also Dialogus de Scaccario, eds. Amt and Church, 96; Curia Regis Rolls 1922-2006, vol.10, 68 (1221).

50 Vincent 2004, 27-34, 43-44; 2007, 299-300 inviting a comparison between the reliability of the pipe rolls and the accounts of Enron or Elf-Aquitaine.

51 Carpenter 2004, 68. 
day Book to the Old Testament and the scriptures of the Jews..$^{52}$ On a less apocalyptic plain, we cannot ignore the emergence of chancery enrolment from the needs of the exchequer, and in particular from the making of the annual exchequer pipe rolls, themselves in existence by 1129 and almost certainly for at least a decade before this. Hence the imperative to preserve details of many thousands of routine financial writs without which, as the Dialogue of the Exchequer makes plain, it would have been impossible to calculate the individual liabilities of the king's debtors, and in particular of the sheriffs. ${ }^{53}$ As this in turn suggests, one other feature deserves attention here: the sheer power of stasis, or the weight of tradition. The rolls were made as they were because they had always been so made; or so at least it was believed by those members of the king's administration responsible for their making, even as early as the 1170s. Once put in place, bureaucratic process tends to wrap itself in the authority of the past, often with remarkable speed. As those of us who encounter bureaucracies are only too aware, ask a bureaucrat why things are done in a particular way, and you will be told that they are done like this because this is how they have always been done; even when the 'always' covers a period of only a few years or even months. ${ }^{54}$ Not only this, but bureaucratic memory is often more fleeting than the processes it seeks to perpetuate. Bureaucrats themselves are all too inclined to remember process but to forget the purposes that such process was designed to serve.

Already, by the 1170s in the writings of Richard fitz Nigel, only a generation or two after the exchequer itself had first acquired a name and an official identity, the exchequer traditions of the 1120 s were outmoded and in many circumstances positively deleterious to the efficient functioning of government. ${ }^{55}$ Events and processes less than fifty years old were either garbled in memory or shrouded in deliberate mystery. ${ }^{56}$ Yet the exchequer and its officials fought tooth and claw to preserve such traditional procedures. ${ }^{57}$ They succeeded, to such an extent, indeed, that various aspects of what passed for protocol in the 1130s were still in place as late as the 1830s, when the very last annual pipe roll came to be written. At the foot of each individual membrane of the 1832 pipe roll, we still find the same style of written memoranda or docquets, reporting the name of the county to which this membrane applied, as in the pipe roll 31 Henry I for the year 1129-1130 (fig. 4). ${ }^{58}$

52 A possibility explored by Vincent 2018, with echoes already present in 'Domesday', as noted by Harvey 2016.

53 Vincent 2004, 20-25.

54 Vincent 2004, 26-27.

55 For example, Dialogus de Scaccario, eds. Amt/Church, 20-21, 62-63, 134-137.

56 Hudson 1992. Even in writing this paper, for which I have consulted a number of former officers of the Public Record Office in Chancery Lane, still functioning as recently as 1997, I have encountered various suprising lapses in collective memory.

57 For a particular instance of such residivism, see Jolliffe 1948. More generally, see Vincent 2017, 121-123.

58 Kew, TNA E 372/676 (pipe roll 2 William IV), with a corresponding chancellor's roll, today E 352/612. 


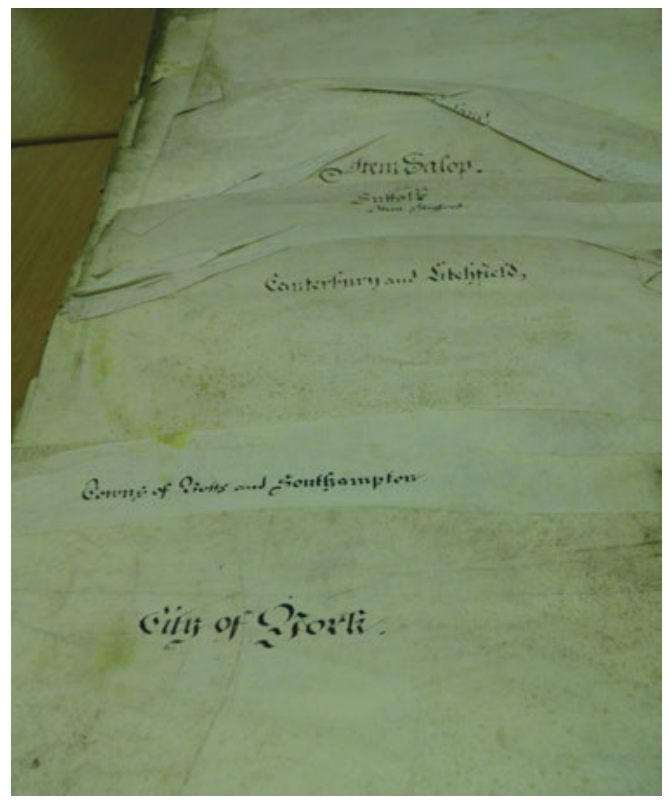

Fig. 4: Pipe roll docquets 1832.

Not only this, but the docquets and the written headings of the 1129 pipe roll carry us back to an even more ancient tradition of such things. As pointed out by Alex Rumble, the capitalized headings and docquets of 1129 were themselves directly modelled upon the handwriting styles of Domesday Book. ${ }^{59}$ And who can say what form of script Domesday Book itself was attempting to replicate? What we have here may well be something more ancient than either 1129 or 1086: a tradition, maintained into the 1830s, that carries echoes of the Anglo-Saxon past as far back as the time of Edward the Confessor, perhaps even further. Similar things occurred in the chancery. The king's itinerant scribes and clerks were undoubtedly responsible for the production of enrolments as early as the time of the first exchequer pipe rolls. Only after 1199 and the accession of King John, it seems, did they resort to more elaborate experiments in enrolment. But these innovations too were swiftly transformed into an age-old tradition, with the king's outgoing letters by 1201 already arranged by three-fold division into rolls of charters (continued through to 1517, and thereafter as confirmation rolls through to 1626), letters close (continued to 1903) and letters patent (the longest-lived of all the chancery series, still ongoing in 2019, some 818 years after its first surviving exemplar). ${ }^{60}$ Other series with similar, if not quite such longevity, include the parliament rolls (more than 720 years of continuous existence from the 1280 s to the present day), pipe rolls (at least 703 years from 1129 to 1832), close rolls (700 years, discontin-

59 Rumble 1991.

60 A point explored by Vincent (forthcoming b). 
ued 1903), and the exchequer originalia rolls (638 years of existence, discontinued 1851). ${ }^{61}$

As this suggests, stasis itself can, on occasion, be used to recover details of the past that might otherwise go entirely unremarked. If we want to understand the workings of the thirteenth-century schools of Paris, a glance at the curriculum of sixteenth-century Oxford would be no bad place to start. If we want to visualize English government at work in the 1250s, we could do worse than look to the writings of Charles Dickens on the Red Tape of the 1850s. ${ }^{62}$ Let us pause here with the pipe roll docquets of 1129 , specifying the contents of the pipe roll county-by-county, still ongoing in 1832. The docquets, of course, were intended to enable those using the rolls to find their way speedily to particular details. More generally, however, they reflect a rather more significant aspect of organization within the king's archive. The pipe rolls were organized county-by-county or sheriff-by-sheriff. So too, of course, was Domesday Book. So too were various of the later attempts to update Domesday, including the great county-by-county surveys of 1212, 1242 and in due course, the hundred rolls enquiries of the 1270 s. $^{63}$ So too, from the 1190 s onwards, were the so-called feet of fines recording judgments in the king's courts. ${ }^{64}$ County names were supplied in the margins to the judicial plea and exchequer memoranda rolls as a means of breaking down an otherwise indigestible body of information into identifiable subsections. ${ }^{65}$ But, all told, this was a system of organization by 'shiring' that carries us back far beyond 1066, at least as far back as the reign of King Edgar (d.975), and arguably King Alfred (d. 899).

By the 1160s, of course, when the king commanded the most ambitious inquest into landholding attempted since 1086, landholding itself was best investigated barony-by-barony, tenant by tenant, rather than on a county-by-county basis. ${ }^{66}$ By the same token, according to the latest thinking, even the returns to the Domesday in-

61 Kew, TNA, SC 9/1-27 (exchequer parliament rolls, 1290-1321); C 54 (close rolls), with the very first in the series misidentified as liberate rolls, C 62/1-3, cf. above note 42); C 65/1-7866 (parliament rolls from Edward III onwards, 122 of these rolls being medieval); E 371/1-1102 (LTR originalia rolls 12131851, the first 250 of these being medieval).

62 A point explored by Vincent (forthcoming $b$ ).

$63 \mathrm{Kew}, \mathrm{TNA}, \mathrm{SC}$ 5, whence Rotuli Hundredorum 1812-1818.

$64 \mathrm{Kew}$, TNA, CP 25/1, where the county-by-county arrangement dates at least to the fourteenth century, and probably earlier than this, although originally the files were divided between fines produced in the central courts (bench and king's bench) and those produced in the local eyres. The fines themselves are supplied by their scribes with county names, sporadically from May 1191, some time before the first institution of the Feet of Fines proper in 1195, with the process stabilized and standard by 1196: Feet of Fines of the Reign of Henry II and of the First Seven Years of the Reign of Richard I, AD 1182 to AD 1196 1894, esp. nos. 8, 13, 15, 18-19, 21.

65 As retained in the published editions of Curia Regis Rolls 1922-2006, and for images see, for example, Palmer/Palmer/Jenks (s. d.), http://aalt.law.uh.edu/H3/KB26_230/0001.htm (accessed: 24.8.18) and ibid., http://aalt.law.uh.edu/H3/E159no26/aE159no26fronts/IMG_0062.htm (accessed: 24.8.2018). 66 For the 1166 survey, and pending the appearance of Neil Stacy's new edition of the return (Pipe Roll Society forthcoming), see below note 108. 


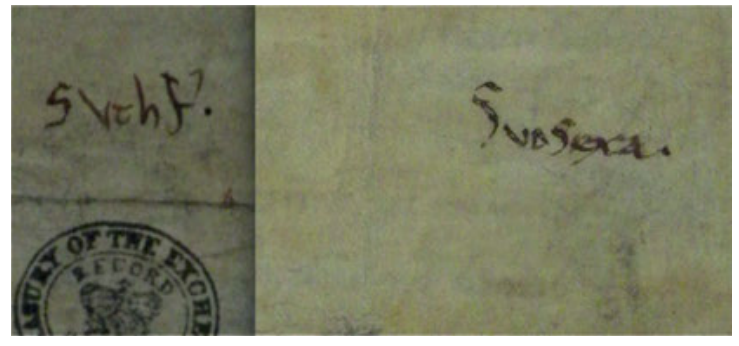

Fig. 5: Endorsements to the returns of 1166 .

quest of 1086 involved a massive degree of baronial co-operation, returned for the most part on a self-certifying basis, baron by baron, and only then digested into a format that could be put for questioning before jurors, county-by-county or hundred-by-hundred. ${ }^{67}$ The returns of 1166 were similarly self-certified, baron-by-baron. Only later were they rearranged in files in the king's archive, organized roughly county-by-county according to the shire in which any particular baron habitually resided or answered to the exchequer. It was in this county-by-county arrangement, fifty or more years later, that the files were awoken from their archival slumbers and copied into the two later registers known as the Black Book and Red Book of the Exchequer ${ }^{68}$. Even as early as the 1160s, however, when we examine the two originals that survive from what was once a series of more than 120 such returns dispatched to the king, these two, in the names of Hilary bishop of Chichester and Roger de Clare, earl of Hertford, are endorsed or docqueted, in the same or a very similar contemporary mid twelfth-century hand, typical of the exchequer or treasury, Sudsexa and Suthf(olcia) (fig. 5). ${ }^{69}$ Following in the same tradition as the Black and Red Books, in 1302 the exchequer compiled a new and massive two-volume 'Book of Fees'. Into this were copied a series of feudal returns made in some instances more than a century before, from 1198 via the great surveys of 1212 and 1235 to that of $1242 .^{70}$ Most of these had been made on a county-by-county basis, surviving thereafter as small rolls stored in a box or other container in the king's archive, known from its outside markings as "Neville's Head" (Testa de Nevill). Even so, included here were a number of surveys originally made barony-by-barony, only later assigned to appropriate county heading in an arrangement still confusing for those perplexed to find returns, in theory for

67 This according to the recent thinking of Stephen Baxter, 'How and Why was Domesday Made?', a paper given at the 40th Battle Conference on Anglo-Norman Studies (Paris 2018), soon to be published in the Haskins Society Journal, in many ways building upon Baxter's earlier enquiry into the Domesday return of Wulfstan of Worcester: Baxter 2001, esp. 81-93.

68 Kew, TNA, E 164/12 (Black Book), whence Liber niger Scaccarij, ed. Hearne, vol.1, 49-340, also in TNA E 164/2 (Red Book), whence The Red Book of the Exchequer, ed. Hall, vol.1, 186-445.

69 Kew, TNA, E 198/1/3 nos.1-2, whence The Red Book of the Exchequer, ed. Hall, vol.1, 198-200, 403-407, and facsimile opposite viii.

70 Kew, TNA, E 164/5-6, whence Liber Feodorum, ed. Maxwell-Lyte, printed earlier in a wholly inadequate edition as Testa de Nevill sive Liber Feodorum in curia scaccarii, eds. Caley et al. 
a single county such as Staffordshire, in reality dealing with estates in up to half a dozen other shires. ${ }^{71}$ It has been suggested that the 1302 'Book of Fees' followed an order, county-by-county that was essentially the same as that of Domesday. ${ }^{72}$ This is to exaggerate the extent to which the county-by-county ordering of Domesday, the pipe rolls, the Red Book, or the 'Book of Fees', adopts any standard routine. At best, what we observe here is a tendency to view England from south-east to north, beginning with the counties closest to London, and thereafter extending in a more or less linear progress, via the south-west and the Midlands to Yorkshire and Northumbria. ${ }^{73}$ Even so, the shire remained the organizing principle here, from the tenth century through to the fourteenth, indeed through to local government reform in the 1970 s or even to the present day.

Meanwhile, endorsements, docquets, marginalia and other archival protocols organized county-by-county and office-by-office were already employed in the twelfth century to sort a vast mass of individual parchment sheets into usable sequence. This should come as no surprise. From the very earliest times, archival endorsements had been a feature of documents issuing from, or stored not only by the exchequer but by the royal secretariat, later chancery. It has recently been observed by Rob Gallagher and Katie Wiles, for example, that a high proportion of original single-sheet Anglo-Saxon royal diplomas, perhaps as many as 20 of those that survive in the British Library and elsewhere from the reign of $A$ thelred onwards, are endorsed in the pre-Conquest English vernacular, these endorsements reporting brief but relatively standardized details of their contents. ${ }^{74}$ Long before royal letters and charters came to be copied into rolls in the chancery, or books came to be made in the exchequer from much earlier enrolled estate surveys, the king's archive was itself obliged to function in place of any more compact attempt at registration. For the creation of such a memory bank, its keepers were obliged to sift and sort things in ways that rendered them as (or in some cases rather more) useful than anything that a later registrar or copyist could achieve. This too should present few surprises, not least because it has long been recognized that other such medieval royal collections, not least the Capetian archive in Paris, were intended to function as just such memory banks. Louis IX's archive of original charters was duly arranged within individual layettes, collectively

71 Maxwell-Lyte 1920, x-xvii. The original returns are today Kew, TNA, E 198/2, including E 198/2/2-8 (returns from King John's reign, mostly to the survey of 1212); E 198/2/13-18 (accounts for the aid taken in 1235-6), and E 198/2/19-27 (returns to the survey of 1242).

72 Maxwell-Lyte 1920, xii, who suggests that although the arrangment of the county entries "is neither alphabetical nor geographical, [...] we may here and there perceive traces of an intention to follow the sequence of the counties as given in Domesday Book".

73 For the closest we come to a conjunction here, Domesday opens Kent, Sussex, Surrey, Hampshire, Berkshire, Wiltshire, Dorset; Liber Feodorum, ed. Maxwell-Lyte, vol. 2 (Kew, TNA, E 164/6), Kent, Sussex, Surrey, Hampshire, Bedfordshire, Buckinghamshire; the 1166 returns as copied into the Red Book, London/Middlesex, Kent, Surrey, Sussex, Hampshire, Dorset, Somerset.

74 Wiles/Gallagher (forthcoming). 


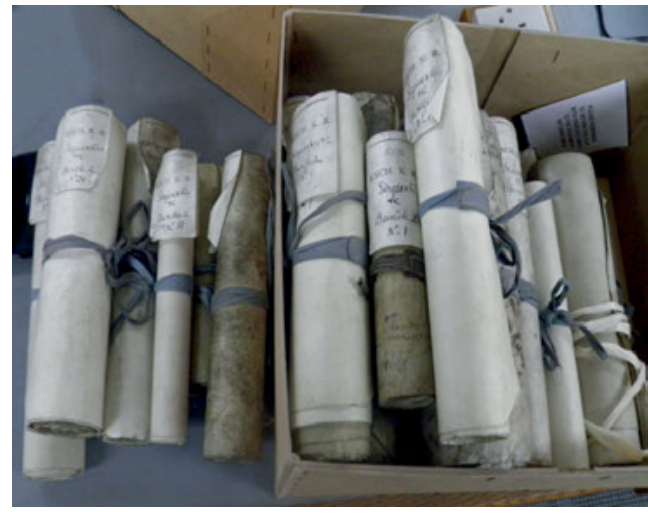

Fig. 6: A selection of the rolls used for the Book of Fees.

making up the so-called trésor des chartes stored in the shadow of the Sainte-Chapelle, albeit here as an essentially closed memorial rather than, as at Westminster, a still functioning part of royal government. ${ }^{75}$

Great Domesday Book, compiled a few months or years after the 1086 survey from which it was derived, achieved an almost miraculous feat of standardized summary. But how much more revealing, in due course, historians have found its rather untidier siblings. Little Domesday and Exon, let alone the so-called Domesday satellites for Cambridgeshire and elsewhere, testify directly to the process of surveying, bringing us even closer than Great Domesday to the gatherings of single-sheet returns from which the Book itself was later digested. These returns of 1086 were themselves founded upon a pre-existing substratum of geld rolls and other fiscal surveys, almost certainly circulating as enrolments rather than as books, that carries us back well beyond the Conquest of $1066 .^{76}$ Domesday itself offered so vast an assembly of facts that, by the mid twelfth-century the officers of the king's treasury where it was stored had already embarked upon attempts to abbreviate its contents or bring particular county surveys up to date. ${ }^{77}$ The 1302 'Book of Fees' is likewise a vast and remarkable achievement, albeit without the organizational genius of Domesday. But how much more useful the 'Book of Fees' is today, now that its most recent editors have peeled away the layers of confusion and mis-transcription applied by the copyists of 1302 and returned us to the original enrolled returns of 1212, 1235 and 1242. These rolls are in many cases still carefully preserved in the National Archives, organized county-bycounty within their particular series (fig.6). ${ }^{78}$ It was precisely the failure of its chief

75 Guyotjeannin/Potin 2005

76 For various of these earlier records, later embedded in Domesday, see Galbraith 1950; Mason 1954; Harvey 1971.

77 Hallam 1986, 42-47, noting Kew, TNA, E 36/284 (Domesday abbreviatio); E 164/1 (Domesday breviate); Oxford, Balliol College, MS.350, whence Galbraith/Tait 1950, xxviii-xxix with details of further Domesday abbreviations or extracts in London, BL, MSS Arundel 153 and Cotton Vitellius C viii.

78 See above note 71. 
editor, Hubert Hall, to undertake a similar process of restoration with the survey of 1166 and its successors that renders the modern edition of the Red Book of the Exchequer an object-lesson in how not to do such things. ${ }^{79}$ In the meantime, by no means every great inquest or endeavour originally returned in single-sheet or enrolled form was later copied into the exchequer's books, at least to judge from those of the exchequer's books that survive.

The returns to the 1170 inquest of sheriffs, for example, were preserved in large numbers, for the most part as small square or rectangular parchment slips but extending on occasion to rather larger rolled up parchment sheets. To judge from the scattered remnants that have survived, returned either by towns or by the tenants of particular manors or baronies, these too were organized within the treasury on a county-by-county basis. Having served their purpose in 1170, however, they were not considered worth digesting into book form, even though they were preserved with a degree of care, or at least benign neglect, in the exchequer archive. Only in the 1890s were attempts made to assemble and edit them as a single, albeit heavily depleted body of materials, this edition of 1896 achieving for the enrolled scraps of 1170 what the Red Book had already achieved, more than 600 years earlier, for the disjecta membra of $1166 .{ }^{80}$ Like the returns from 1170 , Henry II's 1185 inquest into widows and wards, returned hundred-by-hundred, was never recopied or indexed, but instead survives as a roll of twelve membranes, each membrane dealing with a particular county, varying in size from a single entry for Middlesex to several dozen from Lincolnshire. ${ }^{81}$ For analogies here, we might turn not only to the miscellaneous records of the Parisian chambre des comptes, clearly of vast extent although today largely unfathomable as a result of their wholesale destruction in the fire of 1737, but to other such European archives that have survived more or less intact. These would include the records of the fourteenth-century chambre des comptes at Lille, and perhaps most obviously analogous to the parchment slips of Henry II's 1170 inquest, various of the mid twelfth-century fiscal accounts and petitions from Catalonia, today preserved in the Archivo de la Corona de Aragón at Barcelona. ${ }^{82}$ Across medieval Europe, in other words, administrations constructed stores of memory for themselves in which geography (the shires

79 Whence, notoriously, Round 1898.

80 Today mostly surviving as a series of 59 small fragments written in a variety of hands, now Kew, TNA, E 198/1/3, no.3, parts 1-59 (whence Red Book of the Exchequer, ed. Hall, vol.2, cclxvii-cclxxi), with strays now C 47/34/7 (endorsed Wirecestresira, and C 146/10018, whence Tate 1924; Richardson 1940 (with facsimile); Suggett 1942-1943. Of these, there are contemporary endorsements to E 198/1/3, no.3, parts 28 (Baronia Henr(ici) de Ria), 40 (Baronia Roberti filii Hug(onis)), and 46 (Bar(onia) Rob(erti) de Waliunnes).

81 TNA E 198/1/2, whence Rotuli de dominabus et pueris et puellis de xii comitatibus (1185), ed. Round, esp. 88 for Middlesex.

82 For Paris, Nortier 1965. For Lille, Santamaria 2012. For Barcelona, Fiscal Accounts of Catalonia Under the Early Count-Kings (1151-1213), ed. Bisson, esp. vol.2, facing page 167, for a series of facsimiles; Bisson 1998. 
of England, the duchies and regions of the trésor des chartes, the various towns and administrations of Catalonia) was adopted as a key organizing principle.

Meanwhile, far from representing some sort of primitive stage along the highway of progress from medieval to modern, the English roll form can in many instances prove more useful, more revealing and even more enduring than the codex form into which it is considered to have evolved. English government's addiction to enrolment was, to this extent, the result not merely of bureaucratic stasis but of very practical considerations of utility. Here we need to approach these records rather less like modern scholars, convinced of the pre-eminence of the book, the alphabetical card index or the electronically searchable database, and rather more like royal officials of the twelfth and thirteenth centuries aware of different priorities and restraints. To its modern users, the roll form may appear impractical, both in manipulation and sheer quantity. It is taken for granted that a modern edition, like that of the 'Book of Fees', with its careful pagination and its massive index collating and identifying thousands of individual person and place names, is necessarily an improvement over anything that the twelfth or thirteenth centuries could produce. Only when digested or reduced into such modern editions, it is supposed, can the rolls themselves be properly 'used'. But in reality, the rolls were used, with a fair degree of satisfaction to their makers and readers, long before they were properly listed in the seventeenth century, let alone transformed by editorial or indexing conventions into modern scholarly editions. For an analogy, take the example of the Bible. Scripture was read, memorized and subjected to intense exegetical scrutiny long before its division into numbered books and chapters, and even longer before the emergence of the first, only partially successful, alphabetical concordances. ${ }^{83}$ In the same way, the rolls served functions and facilitated enquiries that we today might consider unimaginably difficult without the particular research tools to which we have in many cases only recently grown accustomed.

As a starting point here, let us consider the pipe rolls of the royal exchequer, themselves so often cited as an instance of bureaucratic anachronism run riot. There is no doubt that the priorities of compiling the pipe roll, from the 1120 s onwards, lay behind the making of other formats of enrolment, not least the later chancery fine and close rolls, these latter beginning as rolls of writs or settlements negotiated in the itinerant royal court, considered essential to the accounting processes of the exchequer. As we have seen, the great roll of the exchequer was known to the author of the Dialogue as the "annual roll" or indeed merely as the "annal", a terminology still being employed in the fourteenth century. ${ }^{84}$ But already, from at least the 1290 s, it had acquired another more familiar name: rotulus pipae, or "pipe roll”. The Dictionary of Medieval

83 R. Rouse/M. Rouse 1974, and more generally, of course, Carruthers $2008^{2}$.

84 Red Book of the Exchequer, ed. Hall, vol.3, 850 (grant roule qi est appelle roule annal), 858 (roule annal), both from 1323. 
Latin suggests that this terminology of 'pipe' rolls can be traced as far back as the $1160 s .{ }^{85}$ But the Dictionary is at fault here for citing references that in reality identify the Staffordshire place-name "Pipe" (as in Pipe Ridware and so forth) in the exchequer roll for $1167 .{ }^{86}$ In reality, the Dictionary's earliest citations of "pipe” or "pipes" used in the sense of parchment sheets of account dates from after $1300 .{ }^{87}$ These in turn reveal the modern term 'pipe roll' (in French la pipe) to be a mistranslation of Latin that invariably includes a genitive element rotulus pipae ${ }^{88}$ We are in fact dealing here with "a roll of the pipe", or occasionally, in the plural, with "a roll of pipes": in other words with a gathering together of parchment sheets that both individually and collectively were known as pipa/pipae, almost certainly because they could be rolled up into something resembling a pipe or hollow tube. ${ }^{89}$

To modern readers, these rolls may appear both bulky and baffling. To their users, however, they offered a variety of practical advantages. Sheet by sheet, or as we should perhaps refer to them 'pipe by pipe', the individual membranes that later went to make up each roll could be handled, marked up and corrected, much as a modern copy-editor might correct a large sheet of galley-proofs. In the exchequer itself, as this should remind us, the pipes were handled, to begin with, not in bulky roll form, but one-by-one as single, large parchment sheets. Echoes of this practice can be found in the surviving loose sheets of exchequer pipe and memoranda rolls, from the thirteenth century onwards, today surviving in distinct National Archives classes. ${ }^{90}$ Even when the pipes were sewn and rolled up together into a pipe roll, with each parchment membrane joined to its fellow membranes head-to-head, the outcome was something that in basic form was little different from a book, albeit a book presented in giant picture format, 'sideways on', with the sewing together of the membranes

85 Ashdown et al. 1975-2013, 2287.

86 The Great Roll of the Pipe for the Thirteenth Year of the Reign of King Henry II, AD 1166-1167 1889, 52-53.

87 Account of the Executors of Richard Bishop of London 1303 and of the Executors of Thomas Bishop of Exter 1310, eds. Hale and Ellacombe, 104, referring to various debts que currebant in pipa, owed to the King. Slightly earlier than this, see, from 1297 onwards, references in the so-called pipe rolls of the bishops of Winchester to money spent on buying parchment ad pipas, as noted by Mayberry 1988, 5.

88 Red Book of the Exchequer, ed. Hall, vol.3, 850 (La Pipe alias the grant roule qi est appelle roule annal, 1323), 858-860 (noting that the roule annal/grant roule should involve writing with capitalized headings and without erasure and that tutes les pipes de tutz les accomptes renduz en lan bien et pleynement examinez avant qe eles soient mises ensemble, et roule fait de eles a la fyn del an), 874 (lacompte en Pipe), 936 (et qe les pipes des acountes soient bien escrites et examinees, 1326).

89 Ramsay 1911 (nonetheless striving to render the word 'pipes' not as related to tubes but in some way to strips or staves, as in musical notation); Poole 1912, 150-151. By contrast, the Exchequer officials themselves, from at least as early as the seventeenth century, peddled much nonsense suggesting that the name derived from the idea of the treasury as a reservoir into which all revenue was drained via one main conduit (or 'pipe'): Introduction to the Study of the Pipe Rolls 1884, 42-43, with echoes thereafter in Madox.

90 Kew, TNA, E 160/8-25; E 352/613-614; E 389/323. 


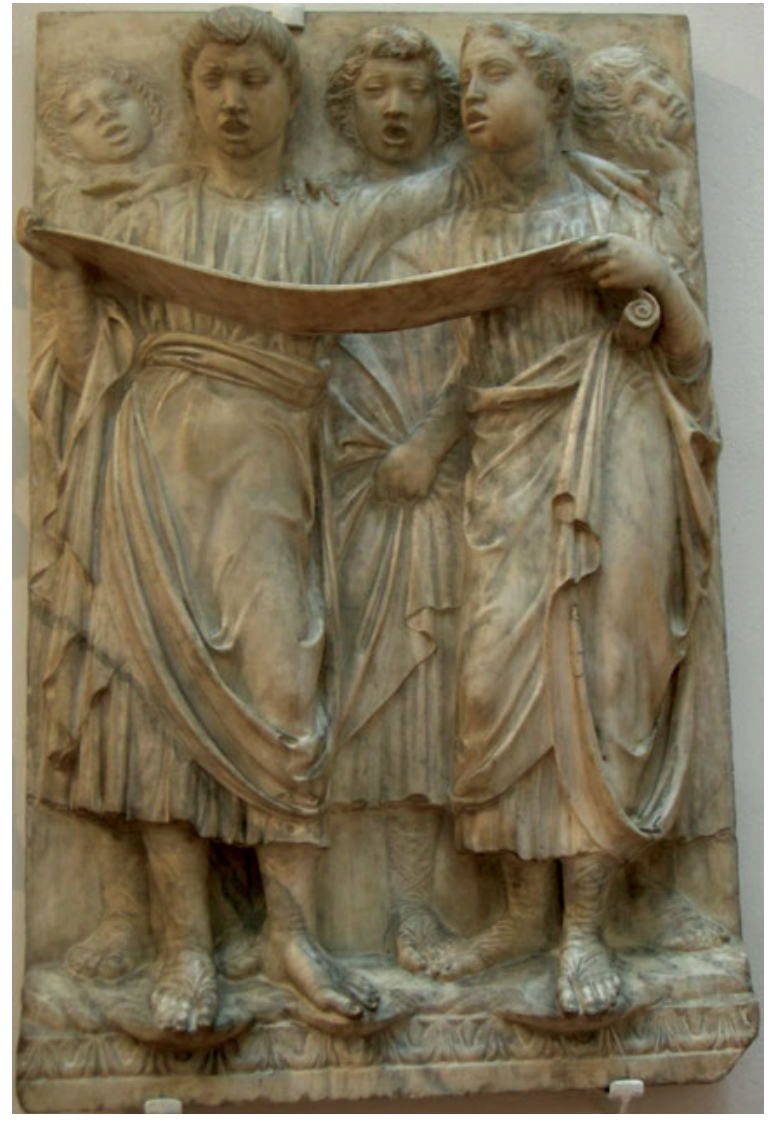

Fig. 7: Detail from Luca della Robbia's cantorie, Florence.

equivalent to the binding of a modern codex, but with the roll itself still 'openable' in essentially the same way as a book. ${ }^{91}$ It was precisely this format of enrolment, head-to-head, that was adopted not only in the exchequer but in the king's law courts, all of which continued to produce rolls that were in essence monstrously oversized books presented 'sideways on'. Rather like the giant liturgical rolls or codices used by choirs (portrayed most famously in Luca della Robbia's cantorie in the Duomo at Florence), they possessed a further advantage in that they could be consulted from two or three sides and hence by upwards of two or more readers simultaneously (fig. 7). Not only this, but with only a stiff layer of polished sheepskin rather than heavy wooden boards to serve as their outer-covering, even when sewn up into rolls, they remained far lighter, and hence more easily transportable than any book of an equivalent size. This would have been a distinct advantage for records of an office like the exchequer that, even as late as the fourteenth century, continued to migrate between London and York. With their docquets and annotated feet, moreover, the rolls prefigured such later

91 Carpenter 2004, 67. 
administrative inventions as the docqueted account or address book, today marketed with dividers or stepped 'cut away' pagination in place of docquets, but according to principles similar to those already adopted for the pipe rolls as long ago as 1129. Far from being impractical, therefore, it was the very utility of the parchment sheet, and in due course, the gathering together of such sheets into rolls that determined their selection as a form of choice by both the exchequer and the king's justices.

Elsewhere, in the preservation of royal letters rather than accounts or pleas, things developed rather differently. The 'pipe roll style', favoured in exchequer and law courts, is characterized by the sewing of its many long membranes head-to-head. This was a format intended for consultation and use. In the chancery, by contrast, and in that part of the exchequer concerned to preserve copies of chancery-produced letters in the so-called cartae antiquae rolls, the individual membranes on to which royal letters were copied were stitched not head-to-head but head-to-foot, creating in the process a single spool of parchment sometimes tens of metres long. Broken only by stitch marks, rather like a modern lavatory roll, this could then be laboriously rolled and unrolled (fig. 8). The intention here, in deliberate differentiation from the exchequer format, was to create a format suitable for record rather than daily use. Those today confronted by rolls in this 'spool' format are often disconcerted by the format's inconvenience. It requires considerable time and patience to unroll the longer records, and, as with a spool of modern microfilm, there is always the risk that the process will gather excess momentum, propelling lengths of parchment across desk and then floor, much to the reader's embarrassment. Yet here too there was an element of utility, suited to a format intended for record rather than use. Anyone who has consulted the inner membranes of such a spool can testify to the relatively pristine conditions that pertain on all save the outermost membranes of the chancery rolls. In other words, and by contrast to the relatively exposed membranes of an exchequer-style enrolment, the membranes used in chancery served as self-preserving wrappers, each new layer affording greater protection to the membranes that were rolled up further towards the centre. As with the exchequer rolls, so with the unbound rolls of the still itinerant chancery, the lack of heavy boards made transportation more practical. Given the chancery's apparently limitless access to copyists, parchment and ink, even the difficulties of manipulating the rolls assume a rather different significance. Far from representing a difficulty, indeed, they may have appeared of very practical advantage to those who first commanded the making of such rolls.

To understand this, let us return to one of the more important distinctions between medieval enrolments and their modern editions. The medieval rolls were organized according to clear principles. The chancery rolls, on the whole, followed date order for the copying of individual letters, so that once categorized as letters patent, letters close, or as charters, individual items were copied and preserved in roughly chronological order. The more solemn charter rolls were further supplied with marginalia identifying the beneficiaries of particular charters, the other rolls with marginal notations of a rather less formal variety. The rolls of the law courts were likewise chronologically 


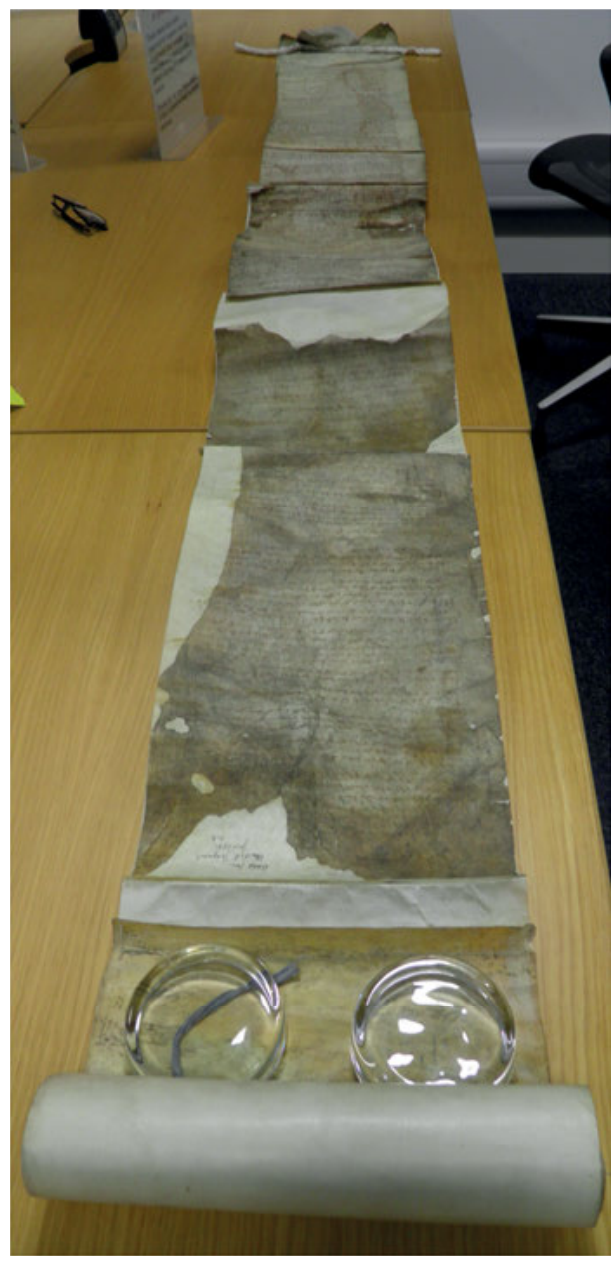

Fig. 8: Unrolled chancery roll.

arranged, with case following case according to the dates at which hearings occurred, but with marginalia identifying each entry by its particular county..$^{92}$ The rolls dealing with royal finance were in some instances chronological, as with the receipt and issue rolls recording payments to and from the exchequer. The pipe and memoranda rolls, however, were differently organized. The pipe rolls were arranged county-by-county, but enrolled in no fixed order (say from Kent to Yorkshire) but roughly according to the date at which each sheriff accounted, from Michaelmas onwards. The exchequer memoranda rolls were arranged according to a series of criteria determined first by the basic type of business transacted, these sub-sections then arranged in more or less chronological sequence according to the principle terms at which the exchequer convened,

92 To date, these marginalia have gone largely ignored. Adam Chambers, of King's College London, is presently engaged on a more detailed study of the process of enrolment in chancery under Henry III. 
with marginalia identifying the particular counties concerned. ${ }^{93}$ Modern editions, on the whole, preserve these basic divisions, and in some instances the marginalia, but with an assumption that modern readers expect to find not only marginalia but a concluding, detailed and alphabetically arranged index.

The rolls themselves had no such indexes. Instead, their readers made do with rather less efficient searching aids. In chancery, these included marginalia intended to offer guidance to particular items of business. In the exchequer, it extended to the docquets at the foot of each membrane, and thereafter the careful arrangement of business either into distinct 'paragraphs' in the pipe and chancellors' rolls, or 'sections', themselves with marginal headings county-by-county, in the case of the memoranda rolls. By such means, the rolls could be searched. Even earlier than this, the scribe of Domesday and its various satellites had striven to make the pages of the book, and the membranes of various rolls, less visually monotonous, with clear breaks and spacings, capitalized headings and other aids to consultation. ${ }^{94}$ Rather than make the good the enemy of the best, we should recognize the thought and effort that went into such an apparatus. Certainly, we can hardly ignore the fact that the rolls, far from being unsearchable, were regularly and often successfully scoured for information. The expectation of such searches was a feature of the pipe rolls from their first inception. Later, in the case of the chancery enrolments, it spawned its own subseries of 'extract rolls', in which copies were made from close, patent and charter rolls, for particular needs and in particular circumstances. ${ }^{95}$

From the time of the earliest surviving records of the king's law courts, we read of many such record searches. As early as 1200, these included searches of court and justices itinerant rolls, apparently reaching as far back as the 1170s, on one occasion referring to such a court roll as the magnum rotulum. ${ }^{96}$ From much the same time we read of searches made in the rolls of county courts (now entirely lost for this early

93 Conway Davies 1957, esp.107-20, with further information online at http://discovery.national archives.gov.uk/details/r/C6604 (last accessed: 31.7.18).

94 For a sometimes over ingenious survey of such devices, see now Roffe 2016.

95 Kew, TNA, C 59/1-47 (Henry III-Edward III). Apart from this 'official' series, many dozens of such rolls of extracts could be found, scattered across the records of chancery and exchequer. See, for example, Kew, TNA, E 132/1-3 (66 rolls or single-sheet copies, continuing the series of cartae antiquae rolls C 52); E 163/1/7 and E 163/1/9 (chancery style, enrolled copies of the 1250s, from charter, close and patent rolls, including extracts from the lost charter rolls 18 and 40 Henry III, relating to Wales, Ireland and Gascony). The existence of a now lost extract roll covering at least part of the reign of King John is implied by Curia Regis Rolls 1922-2006, vol.10, 125 (de ballia Iohannis regis patris nostri ad voluntatem suam sicut patet in rotulo de extractis, 1221).

96 Curia Regis Rolls 1922-2006, vol. 1, 57, 181, 208 (of the time of Richard de Lucy), 402; vol. 2, 19, 197, 262-263; vol.3, 20 (a "roll of Theobald"), 168, 170; vol.4, 35-36; vol.6, 260, 308, and cf. vol.2, 218; vol. 3, 45, for one such early court roll referred to as the "Roll 1 Richard I". For the deliberate archiving of such plea rolls in the treasury, see Curia Regis Rolls 1922-2006, vol. 8, 114, reporting the presence there of an earlier roll (for the year 1200, cf. Ibid., vol.1, 216). 
period), and of searches amongst the final concords. ${ }^{97}$ On occasion, too, we find the courts commanding searches of the exchequer archives, including pipe rolls. ${ }^{98}$ It is nonetheless highly significant that at this early date we find no references to chancery, as opposed to exchequer enrolments being searched. A charter of King John in favour of Robert of Thurnham, said to have been found in 1219 "enrolled at the exchequer", may be the first such chancery enrolment whose use was reported in the plea rolls. ${ }^{99}$ Alternatively this might just as easily refer to the exchequer's cartae antiquae rolls, as was undoubtedly the case with other royal charters reported as being in rotulis de scaccario from about the same time. ${ }^{100}$ Thereafter, we have to wait until 1239 to find specific chancery rolls being cited as evidence in the king's law courts. None of the rolls here cited is earlier than the reign of King John. ${ }^{101}$ Even so, on rare occasion we find the chancery rolls being used to verify or disprove royal charters of John's reign, as for example in 1280, when the justices of Edward I were able to prove that a charter supposedly granted to the men of York, dated in the year 4 John (July 1202), had in fact been deliberately falsified by erasure, thereby backdating liberties in reality not granted until 1212. ${ }^{102}$ Before the late 1230s, meanwhile, the absence of references to judicial search of chancery enrolments supplies one of our more powerful arguments, necessarily ex silentio, that the chancery possessed no such rolls earlier than the reign of King John. ${ }^{103}$ The fact that in 1201 the king's justices employed the term rotulos de Westmonasterio to refer to their own court rolls rather than evidences of either the exchequer or the chancery, points in much the same direction. ${ }^{104}$

97 Curia Regis Rolls 1922-2006, vol.1, 245 (final concord of the time of Richard de Lucy); vol. 2, 260, 296 (possibly county court rolls for Oxfordshire as early as 1203); vol. 6, 208, 230 (county court roll for Gloucestershire, 1212).

98 Curia Regis Rolls 1922-2006, vol.1, 436 (rotulos scaccarii, 1201); vol. 8, 295; vol.12, no.319; vol.13, nos. 612, 1735, 2201.

99 Curia Regis Rolls 1922-2006, vol. 8, 46: Rex Iohannes [...] cartam suam inde fecit que inrotulata est ad scaccarium, referring to a grant to Robert, apparently as Rotuli chartarum in turri Londinensi asservati, ed. Hardy, 173b (15 December 1207).

100 Curia Regis Rolls 1922-2006, vol.11, no. 891 (a charter of John granting quittance of toll to the bishop of London and his men, inrotulatum ad scaccarium, probably as Kew, TNA, C 52/1, no.12, whence The Cartae Antiquae Rolls 1-10, ed. Landon, 4-5, no.12), 2619 (a charter of Richard I granting privileges to the bishops of Ely, transcriptum [...] in rotulis de scaccario, almost certainly that of 10 October 1189, copied into the cartae antiquae roll Kew, TNA, C 52/2, no. 17 and C 52/33, no.43, whence Cartae Antiquae Rolls, ed. Landon, 30, no. 17).

101 Curia Regis Rolls 1922-2006, vol.16, nos.1001, 1493-1494, 1626, 1758.

102 Kew, TNA, KB 27/53 (Coram Rege plea roll Easter term 8 Edward I), m. 33, noting deliberate erasure of part of the date of a charter, the proof here being obtained in the exchequer (compertum est in scaccario $r$ (egis) quod predicta carta facta fuit anno r(egni) predicti I(ohannis) reg(is) quintodecimo (sic) et dat' in predicta carta rasa). The charter is otherwise preserved as Rotuli chartarum in turri Londinensi asservati, ed. Hardy,187 (9 July year 14, i. e. 1212).

103 Vincent 2004, 43.

104 Curia Regis Rolls 1922-2006, vol.1, 408. 
Such searches were not, of course, as they would be today, conducted with the aid of alphabetical indexes or carefully paginated editions. By no means all were successful. In 1203, indeed, we read of the first reported search of the pipe rolls that failed to produce a particular item of information, here as the starting point for those many tens of thousands of fruitless searches that have since been conducted, either by government officials or by the scholarly community of more recent years. ${ }^{105}$ But the fact that searches were neither easy nor invariably successful does not in any way imply that the rolls themselves were unsearchable, let alone more difficult to search than codices. Books there were, even in the king's law courts, as early as the reign of King John. ${ }^{106}$ By the reign of Edward I, perhaps in deliberate imitation of Flemish or Sicilian practice, the Wardrobe was a department of books as much as of rolls. Yet the fact that so many of these books have themselves been either lost or dispersed away from their original resting place in what were to become The National Archives, is itself an indication that books were by no means necessarily more durable, or more 'useable' than rolls. ${ }^{107}$ Meanwhile, whether through stasis or perceived utility, the roll form continued to proliferate. Even in assuming that stasis or ease of access were primary considerations here, we once again risk imposing modern scholarly priorities upon circumstances in which ease and speed were by no means invariably the chief priorities.

On occasion, twelfth- and thirteenth-century English government was capable of breath-taking efficiency. Take, for instance, Henry II's great survey into English knights' fees. Whether the writs initiating this enquiry were sent out early in 1166, or as has recently (and unconvincingly) been suggested, late in 1165, they allowed only a few weeks for upwards of 300 barons to hold enquiries and dispatch detailed returns, commanded to reach the king by 13 March $1166 .{ }^{108}$ King John initiated his great inquest into tenancies in chief with even greater dispatch. By writs dated 1 June 1212, he commanded his sheriffs to reply to the exchequer by 25 June, barely three weeks later. ${ }^{109}$ Since the sheriffs' responses are in many cases endorsed with the date of their

105 Curia Regis Rolls 1922-2006, vol.2, 299: Nicholaus Presbiter venit et vocauit rotulos magni [? recte magnos] scaccarii ad warantum quod terra capta fuit in manu domini regis, et cum misit nomina thesaurario si ita esset vel non, idem thesaurarius defuit ei de waranto quia non fuit inuentum quod ita esset.

106 See, for example, the liber Martini, apparently a book including names of those to be attached, belonging to the clerk and future chief justice Martin of Pattishall, recorded in Curia Regis Rolls 19222006, vol. 4, vii , 177.

107 For the wardrobe books, many now dispersed from the National Archives, surviving in collections in London, Manchester and elsewhere, see Vincent 2017, and Stefan Holz in the present volume.

108 For the specification of the term for information to be submitted, see the return sent by the archbishop of York, Red Book of the Exchequer, ed. Hall, vol.1, 412, and cf. Round 1898, 62-63. For the date of the initiating writs, see Stacy (forthcoming), correcting Moore 2011. Compare a later survey, commanded on 22 February 1177, by which sheriffs were expected to report on the service owed by tenants-in-chief in time for the Easter exchequer that year: Gesta regis Henrici secundi Benedicti abbatis, ed. Stubbs, vol.1, 138.

109 An original writ of 1 June survives sewn to the Nottinghamshire return, Kew, TNA, E 198/2/6, 
return, we know that only one sheriff (ironically enough, from the most distant county of Cumberland) met the deadline set. ${ }^{110}$ By 2 July, however, and still within a week of the original deadline, returns for a further nine counties had been submitted, leaving only those of the sheriffs of Nottinghamshire/Derbyshire (returned 6 July), Dorset/ Somerset (returned 23 July), and Northumberland (not returned until 5 August). ${ }^{111}$ As a further example, take the Great Cause of the 1290s. Here we find King Edward I writing to the monks of Evesham on 8 March 1291, requesting that they search their chronicles and histories for evidence of relations between the kings of England and Scotland. The monks answered from Evesham, in considerable detail, on 12 March, only 5 days later. ${ }^{112}$ Similar speed undoubtedly governed the Domesday inquest of 1086 , and would have governed the hundred rolls enquiries of the 1270s, if only the sheer quantity of information requested had been kept within more reasonable bounds. ${ }^{113}$ In all of these enquiries, the words of Macbeth might have served as chief motto: "If it were done when 'tis done, then 'twere well it were done quickly".

On other occasions, however, haste or expedition were almost the last things that government demanded of its records. We should recall here the advice supposedly given to Henry II by his mother, the Empress Matilda: that he prolong cases indefinitely as a means of wringing the best possible terms out of those obliged to litigate in his courts. ${ }^{114}$ Never decide today what could be more advantageously negotiated tomorrow, as Henry II's dealings with the famous case of Richard of Anstey more than amply proved. ${ }^{115}$ The returns of 1166 or 1212 were very speedily gathered but were acted upon with far less haste. Delay, in this reading, and even a degree of deliberate inefficiency, were amongst the more powerful weapons of kingship. The significance of such delay, indeed, shines out from the text of Magna Carta in 1215, with its insistence that the king do "nothing to sell, deny or delay justice" (nulli vendemus,

m. 5, whence Red Book of the Exchequer, ed. Hall, vol.2, cclxxxv; Liber Feodorum, ed. Maxwell-Lyte, vol.1, 52, with an undated copy of the same writ also surviving as part of the sheriff's return from Staffordshire, Kew, TNA, E 198/2/5, m. 3.

110 Dates here assembled in Liber Feodorum, ed. Maxwell-Lyte, vol.1, 55-63, at 53 noting that various of these returns were also able to include replies to a royal letter of 7 June 1212, requesting information on alienations made by the exiled clergy. The Cumberland return is ibid., vol.1, 197-200.

111 Liber Feodorum, ed. Maxwell-Lyte, vol.1, 56, 61-62.

112 Kew, TNA, E 39/100/160, whence Documents and Records Illustrating the History of Scotland and the Transactions between the Crowns of Scotland and England, ed. Palgrave, 89-92, and cf. Taylor 2017, 173-174.

113 Raban 2004.

114 Walter Map, De Nugis Curialium, ed. James, revised by Brooke/Mynors, 479 (quod omnia protelaret omnium negocia), 485 (dispendiosus est in suorum negociis), and cf. Gerald of Wales, De Principis instructione liber, eds. Brewer, Dimock and Warner, vol. 8, 160 (iustitie venditor et dilator); Radulfi Nigri Chronica: The Chronicles of Ralph Niger, ed. Anstruther, 169 (in causis differendis cavillantissimus ut saepe ius venderet), various of which references I owe to Henry Summerson.

115 Barnes 1962. 
nulli negabimus aut differemus rectum aut iusticiam $)^{116}$. It is no coincidence, given its importance to all aspects of the rule of law, that this is one of the few clauses of the 1215 Magna Carta that remains on the English Statute Book after more than 800 years. ${ }^{117}$ Yet Magna Carta was a document deliberately not enrolled in chancery, at least through to its final iteration in the 1290s. ${ }^{118}$ Chancery, in other words, like other royal offices, was as expert at forgetting or deliberately misremembering as it was in preserving accurate records of the past.

To a researcher today, working with modern indexes and scholarly editions, less than an hour's work will generally be sufficient to trace the descent of a barony or individual manor from Domesday in 1086, through to the inquisitiones post mortem of Edward I's reign and beyond. By contrast, to those who compiled such records, both in their originally enrolled form, or later as fair copies transcribed into books, no such feats were achievable. But speed and efficiency were not necessarily the chief priorities here, however much their absence may be deplored by modern researchers driven by 'research assessment' exercises and the capitalist work ethic. ${ }^{119}$ Without indexes, Domesday, or the Red Book, or the 'Book of Fees', could be accessed only with difficulty and with severely limited expectation, as vast thickets of partially digested fact, impenetrable save with expert labour and a high degree of serendipity. However, far from being a disadvantage, to the clerks who compiled the rolls and records, or to the individuals who searched them, this was proof that the royal archives were indeed a place of power and awesome majesty.

With this in mind, let us turn to two final questions: to what extent was the roll form a distinctively English or Anglo-Norman phenomenon, and in what ways did its adoption help 'shape' the later medieval English state? In certain places, the adoption of rolls rather than registers does indeed testify to direct English influence. Such was undoubtedly the case in Ireland, and in due course, from the 1260s, Scotland. Similarly deliberate imitation explains why the roll form was adopted from $c .1215$ for the earliest English episcopal "registers", drawn up as rolls under both Hugh of Wells and Lincoln and Walter de Gray at York, in both cases by bishops who were previously servants of the royal chancery, Hugh as clerk and datary, Walter as one-time chancellor. ${ }^{120}$ Elsewhere, however, regimes that adopted the roll form, especially for their accounts, were not necessarily copying English practice so much as arriving at common solutions to problems experienced across medieval Europe: a process of convergent development, or 'homoplasy', rather than parallel evolution from a shared ancestor. Parallels there undoubtedly were. The procedures of the English exchequer, let alone

116 For an online edition of Magna Carta see: http://magnacarta.cmp.uea.ac.uk/read/magna_carta_ 1215 (last accessed: 6.8.18).

117 See here the commentary to Magna Carta clause 40 Summerson (s. d.).

118 Vincent (forthcoming b).

119 In general here, see Warren 1984; Dyer 2000 and various of the essays in the same collection as Dyer.

120 Clanchy 2013³, 76-77; Cheney 1950, 104-108. 
its distinctively Romano-Sicilian vocabulary, already testify, as early as the 1120 s, to influences from across the Alps, most obviously from the Arabists of Spain, and the administrative procedures of Norman Sicily. ${ }^{121}$ Sicily and Italy more generally continued to exert a degree of influence over European accountancy, long into the thirteenth century and beyond. ${ }^{122}$ But to suggest that all regimes that adopted the roll form for their accounts were necessarily aping English methods would be as ridiculous as to suggest that the exchequer in Westminster was merely a pale shadow of some archetype in Palermo or Cordoba.

Just such direct English influence has been inferred both in Poitou and Toulouse, where the administration of Louis IX's brother Alphonse was conducted using a combination of registers and enrolled accounts, and in Savoy, where the roll form became ubiquitous for comital accountancy, from the 1250s onwards. Both Poitou and Savoy undoubtedly enjoyed close associations with the Plantagenet kings of England. Yet in neither Poitou nor Savoy did the roll form, as adopted, conform to the conventions of the English royal exchequer. Nor are the Savoyard or Poitevin rolls presented in the same format as their English equivalents, not least because they record fair copies of accounts already rendered, by contrast to the English exchequer pipe roll which was itself an instrument, not merely a record, of account. ${ }^{123}$ Not only this, but by contrast to England, neither Poitou nor Savoy adopted the enrolment of chancery as opposed to financial records. The exceptions here-the chancery registrations attempted for Alphonse of Poitiers, and a very early cartulary roll closely associated with Peter of Savoy-tend merely to prove the rule. Alphonse's registers followed Capetian French example. Peter's cartulary roll (recording 63 deeds, preserved on seven parchment membranes) was made for his English lands and survives in the English royal archives, almost certainly as a result of English royal initiatives after Peter's death in 1268 , rather than as a record generated by Peter's own chancery. ${ }^{124}$

Meanwhile, did the English enrolments in any way help 'shape' the trajectory of the later medieval English state? Attempting to avoid the teleology and determinism that lurk behind most concepts of state-building, not least behind such concepts as the 'evolution' or 'growth' of the nation-state, historians over the past twenty years have adopted a variety of alternative vocabularies. These emphasize not growth but structural development, the 'thickening' of social or constitutional textures, and even 'co-evolution': essentially a new-fangled equivalent to 'symbiosis', as processes hardened into institutions and as initiatives first launched by the social elite implicated a widening social spectrum in affairs that were increasingly both bureaucratized

121 Poole 1912, 47-53, 68-69; Loud 2003, esp. 550, and more generally, Vincent 2017.

122 Sivery 1978. For further potential channels of transmission here, linking the administrative practices of Sicily and Flanders, see Dunbabin 2011. More generally, see Todeschini 2002; Berkhofer 2004; Lachaud 2010; Sabapathy 2014.

123 Chiaudino 1930, 1933-1938; Guilleré/Gaulin 1992; Chenard 2017, esp. 349ff.

$124 \mathrm{Kew}, \mathrm{TNA}, \mathrm{C}$ 47/9/1, with a full study forthcoming by Huw Ridgeway. 
and politicized. ${ }^{125}$ None of these vocabularies, I would suggest, is entirely free from anachronism. Some, in steering clear of the Scylla of determinism, risk drowning in a Charybdis of fate. Nor, as any number of middle-aged weight-watchers can testify, is it ever a simple matter to distinguish 'thickening' from 'growth'. Ignored, but surely implicit in all of this we tend to overlook a more subtle process of accumulation, both of evidence and experience, that does indeed tell us important things about the shaping of the state. As archives accumulated, so the body politic acquired not merely an enhanced degree of authority and maturity but a memory that itself helped mould the state's identity. The experience of using these archives conditioned both government and its subjects to an approach to the past that in turn helped shape the future. Without fully accepting here the anthropomorphic fallacy of the state as an entity born or nurtured, growing through infancy towards maturity; the mere accumulation of records by 1250, and hence the sheer abundance of the rolls, endowed medieval English government with both a facility and an outlook on the world that it could not have claimed, two hundred years before. This outlook and facility continued to 'thicken', 'evolve', 'mature' thereafter (or for that matter 'coalesce', 'coagulate', 'congeal' or even 'curdle'), as a significant component of late medieval state power.

From the Empress Matilda to Jules Michelet, the English medieval rolls have quite rightly been viewed as a massive, even as a stupefyingly precious resource. In the twenty-first century, as in the 1830s, their users continue to rely upon a degree of 'guess(-work) matured into habit'. ${ }^{126}$ Such reliance on habit, indeed, continues to distinguish the archive-mole, rooting for earthworms in Kew, from his or her more theory-obsessed colleagues, staring at moonbeams in Paris or New York. In proceeding thus, however, even we poor moles may, from time to time, count our worms by moonlight. It is to be hoped that we may do so in future with a conceptual awareness hardly less refined than that of our superlunary colleagues.

125 Watts 2009, esp. 205 for the 'process of constitutional thickening', with a sensitive review by A. Kosto at https://scholarworks.iu.edu/journals/index.php/tmr/article/view/16952 (accessed: 31.7.18). For 'co-evolution', see Forrest 2015.

126 For guess and habit, see above note 9. 


\section{Appendix}

Tab. 1: Principal classes of enrolment in chancery.

\begin{tabular}{llll}
\hline Roll class & $\begin{array}{l}\text { Reference } \\
\text { (all to Kew, TNA) }\end{array}$ & Dates & Number \\
\hline Charter rolls $^{127}$ & C 53 & $1199-1517$ & 200 rolls (198 before 1486) \\
\hline Fine rolls & C 60 & $1199-1648$ & 553 rolls (295 before 1486) \\
\hline Close rolls & C 54 & $1200-1903$ & 20,921 rolls $^{128}$ (380 before 1486) \\
\hline Norman rolls & C 64 & $1200-1422$ & 17 rolls (17 before 1422) \\
\hline Patent rolls & C 66 & $1201-2012$ & 5,886 rolls ${ }^{129}(615$ before 1486$)$ \\
\hline Scutage rolls & C 72 & $1214-1338$ & 13 rolls (13 before 1338) \\
\hline Liberate rolls & C 62 & $1226-1436$ & 234 rolls ${ }^{130}$ (234 before 1436) \\
\hline Treaty rolls & C 76 & $1234-1675$ & 222 rolls (170 before 1486) \\
\hline Extract rolls & C 59 & $1242-1352$ & 47 rolls (47 before 1352) \\
\hline Gascon rolls & C 61 & $1253-1468$ & 144 rolls (144 before 1468) \\
\hline Welsh rolls & C 77 & $1276-1294$ & 7 rolls (7 before 1294) \\
\hline Statute rolls & C 74 & $1277-1469$ & 8 rolls (8 before 1469) \\
\hline Scotch rolls & C 71 & $1290-1516$ & 113 rolls (106 before 1486) \\
\hline Roman rolls & C 70 & $1306-1358$ & 25 rolls (25 before 1358) \\
\hline Confirmation rolls & C 56 & $1483-1626$ & 114 rolls (7 before 1486) \\
\hline
\end{tabular}

Total: $25,504(2,266$ before 1486$)$

127 TNA C 53/1-200 (charter rolls), continued as C 56/1-114 (confirmation rolls, 1483-1626); C 54 (close rolls), spawning a subsidiary series, C 62 (liberate rolls, from 1226 to 1436); C 66 (patent rolls), the latest in the series so far deposited in Kew being C 66/5726 (for the year 55 Elizabeth II, 2006-2007).

128 Including here C 62/1-3 and C 55/1-19.

129 Including the supplementary series C 67/1-96.

130 Excluding here C 62/1-3, counted above as close rolls, but including the series now E 403/12001288. 
Tab. 2: Principal classes of enrolment in exchequer.

\begin{tabular}{llll}
\hline Roll class & $\begin{array}{l}\text { Reference } \\
\text { (all to Kew, TNA) }\end{array}$ & Dates & Numbers \\
\hline Pipe rolls & E 372 & $1129-1832$ & 676 rolls (330 before 1486) \\
\hline Receipt rolls & E 401 & $1160-1782$ & 1,561 rolls (954 before 1486) \\
\hline Chancellors' rolls & E 352 & $1162-1832$ & 612 rolls (276 before 1486) \\
\hline Norman pipe rolls & E 373 & $1180-1203$ & 18 rolls (18 before 1203) \\
\hline Cartae antiquae rolls & C 52 & $1189-1327$ & 47 rolls (47 before 1327) \\
\hline Originalia rolls & E 371 & $1213-1851$ & 1,102 rolls (250 before 1486) \\
\hline Issue rolls & E 403 & $1216-1834$ & c. 2,006 rolls (863 before 1486) \\
\hline Memoranda rolls (LTR) & E 368 & $1217-1835$ & 804 rolls (258 before 1486) \\
\hline Memoranda rolls (KR) & E 159 & $1218-1994$ & 811 rolls (261 before 1486) \\
\hline Exchequer plea rolls & E 13 & $1236-1875$ & 1,502 rolls (170 before 1486) \\
\hline
\end{tabular}

Total: $9,139(3,427$ before 1486$)$

Tab. 3: Principal classes of enrolment in justice.

\begin{tabular}{|c|c|c|c|}
\hline Rolls series & $\begin{array}{l}\text { Reference } \\
\text { (all to Kew, TNA) }\end{array}$ & Dates & Numbers \\
\hline Curia regis rolls & KB 26 & $1193-1272$ & 236 rolls ( 236 before 1272 ) \\
\hline $\begin{array}{l}\text { Eyre and justice } \\
\text { itinerant rolls }\end{array}$ & JUST 1 & $1198-1528$ & 1,603 rolls $(1,602$ before 1486$)$ \\
\hline Coroners' rolls & JUST 2 & $1228-1426$ & 279 rolls (279 before 1426$)$ \\
\hline Gaol delivery rolls & JUST 3 & $1271-1476$ & $>300$ rolls (300 before 1476$)$ \\
\hline King's bench plea rolls & KB 27 & $1273-1702$ & $2,149$ rolls ( 896 before 1486$)$ \\
\hline $\begin{array}{l}\text { Court of common pleas, } \\
\text { plea rolls }\end{array}$ & CP 40 & $1273-1874$ & $4,135$ rolls ( 893 before 1486$)$ \\
\hline
\end{tabular}

Total: 8,702 (4206 before 1486 )

Total of all rolls: 46,445 (of which

9,879 date before 1486 ) 


\section{Manuscripts}

\section{Dublin, The National Archives of Ireland (NAI)}

King's Bench:

KB $1 / 1-2$

\section{Dublin, National Library of Ireland (NLI)}

MS 2556/1

\section{Kew, The National Archives (TNA)}

Chancery: Chancery Miscellanea:

\section{47/9/1}

C $47 / 34 / 7$

C 47/34/19

Exchequer and Chancery: Cartae Antiquae Rolls:

C $52 / 2$

C $52 / 33$

Chancery: Charter Rolls:

C 53/1-200

Chancery and Supreme Court of Judicature: Close Rolls:

C 54/1-20897

Chancery: Supplementary Close Rolls:

C 55/1-19

Chancery: Confirmation Rolls:

C 56/5726

Chancery: Extract Rolls:

C 59/1-47

Chancery: Liberate Rolls:

C 62/1-3

Chancery: Parliament Rolls:

C 65/1-7866

Chancery: Patent Rolls:

C 66/1-560

Chancery: Supplementary Patent Rolls:

C 67/1-53

C 67/94-96

Chancery: Scotch Rolls:

C 71/1-113

Chancery: Ancient Deeds, Series C:

C 147/1018

Court of Common Pleas, General Eyres and Court of King's Bench: Feet of Fines Files,

Richard I-Henry VII:

CP 25/1

Court of King's Bench: Plea and Crown Sides: Coram Rege Rolls:

KB 27/53

Exchequer: Treasury of Receipt: Miscellaneous Books:

E 36/284 
Exchequer: Treasury of Receipt: Scottish Documents:

E 39/100/160

Exchequer: King's Remembrancer: Transcript of Deeds and Charters:

E 132/1-3

Exchequer: King's Remembrancer: Memoranda Rolls and Enrolment Books:

E 159/1-261

Exchequer: King's Remembrancer: Memoranda Rolls, Loose Rotuli:

E $160 / 8-25$

Exchequer: King's Remembrancer: Miscellanea of the Exchequer:

E $163 / 1 / 7$

E $163 / 1 / 9$

Exchequer: King's Remembrancer: Miscellaneous Books, Series I:

E 164/1-2

E $164 / 5-6$

E $164 / 12$

Exchequer: King's Remembrancer: Records relating to Feudal Tenure and Distraint of Knighthood:

E 198/1/3

E $198 / 2 / 2-8$

E 198/2/13-27

Exchequer: Pipe Office: Chancellor's Rolls:

E 352/612-614

Exchequer: Lord Treasurer's Remembrancer: Memoranda Rolls:

E 368/1-258

Exchequer: Lord Treasurer's Remembrancer and Pipe Office: Miscellaneous Rolls:

E 370/1/3-4

Exchequer: Lord Treasurer's Remembrancer: Originalia Rolls:

E 371/1-1102

Exchequer: Pipe Office: Pipe Rolls:

E 372/676

Exchequer: Lord Treasurer's Remembrancer and Pipe Office: Miscellanea, New Series:

E 389/323

Records of the Supreme Court of Judicature and related courts: Records of the Chancery Division:

Chancery Division Cause Books:

J 12

Records of the Supreme Court of Judicature and related courts: Records of the Queen's (King's)

Bench Division: Formerly King's Bench Division Judgment Books:

J 20

Public Record Office: Maps, Plans and Photographs of the Chancery Lane Building:

PRO 50/59

Special Collections: Hundred Rolls and Eyre Veredicta:

SC 5/1-366

Special Collections: Parliament Rolls, Exchequer Series:

SC 9/1-27 


\section{London, The British Library (BL) \\ Additional Charters:}

Add. Ch. 26515

Arundel:

MS Arundel 153

Cotton:

MS Cotton Vittelius C viii

\section{Oxford, Balliol College}

MS 350

\section{Printed sources}

A Roll of the Proceedings of the King's Council in Ireland: For a Portion of the Sixteenth Year of the Reign of Richard the Second, 1392-3 (1877), ed. James Graves (Rerum Britannicarum medii aevi scriptores 69), London.

Account of the Executors of Richard Bishop of London 1303 and of the Executors of Thomas Bishop of Exter 1310 (1874), eds. William H. Hale and Henry T. Ellacombe (Camden Society, new ser. 10), London.

Calendarium rotulorum patentium in turri Londoninensi (1802), London.

Calendarium rotulorum chartarum et inquisitionum ad quod damnum (1803), London.

Chartae, Privilegia et Immunitates: Being Transcripts of Charters and Privileges to Cities, Towns, Abbeys, and Other Bodies Corporate 18 Henry II to 18 Richard II (1171-1395) (1889), Dublin/ London.

Close Rolls of the Reign of Henry III: Preserved in the Public Record Office (1902-1938), 14 vols., London.

Close Rolls of the Reign of Henry III: Suppl. 1244-1266 (1975), ed. Anne Morton, London.

Curia Regis Rolls: Preserved in the Public Record Office (1922-2006), 20 vols., London.

Dialogus de Scaccario: the Dialogue of the Exchequer. Constitutio Domus Regis: Disposition of the King's Household (2007), eds. Emilie Amt and Stephen D. Church (Oxford Medieval Texts), Oxford.

Documents and Records Illustrating the History of Scotland and the Transactions between the Crowns of Scotland and England, Preserved in the Treasury of Her Majesty's Exchequer (1837), ed. Francis Palgrave, London.

Facsimiles of National Manuscripts of Ireland: From the Earliest Extant Specimens to A. D. 1719 (1874-1884), ed. John Thomas Gilbert, 5 in 4 vols., London/Dublin.

Feet of Fines of the Reign of Henry II and of the First Seven Years of the Reign of Richard I, A. D. 1182 to A. D. 1196: Printed from the Originals in the Custody of the Right. Hon. The Master of the Rolls, under the Direction of the Council of the Pipe Roll Society (1894) (Publications of the Pipe Roll Society 17), London.

Fiscal Accounts of Catalonia Under the Early Count-Kings (1151-1213) (1984), ed. Thomas N. Bisson, 2 vols., Berkeley.

Gerald of Wales, De principis instructione liber, in: Giraldi Cambresensis, Opera (1861-1891), eds. John S. Brewer, James F. Dimock and George F. Warner, 8 vols., London.

Gesta regis Henrici secundi Benedicti abbatis (1867), ed. William Stubbs (Rerum britannicarum medii aevi scriptores 49, 1-2), 2 vols., London. 
Herefordshire Domesday, circa 1160-1170: Reproduced by Collotype from Facsimile Photographs of Balliol College Manuscript 350 (1950), eds. Vivian Hunter Galbraith and James Tait (Publications of the Pipe Roll society, new ser. 25), London.

Liber Feodorum: The Book of Fees Commonly Called Testa de Nevill. Reformed from the Earliest MSS. by the Deputy Keeper of the Records (1920-1931), ed. Henry C. Maxwell-Lyte, 3 vols., London.

Liber niger Scaccarij (1728), ed. Thomas Hearne, 2 vols., London.

Magnum Rotulum Scaccarii vel magnum rotulum pipae de anno tricesimo-primo regni Henrici primi (1833), ed. Joseph Hunter, London.

Memoranda Rolls Preserved in the Public Record Office: Michaelmas 1231-1233, 16-17 Henry III (1991), ed. R. Allen Brown, London.

Michelet, Jules, Journal: tome 1 (1828-1848) (1959), ed. Paul Viallaneix, Paris.

Placita de quo warranto temporibus Edw. I. II. \& III. in curia receptae scaccarij Westm. asservata (1818), London.

Placitorum in domo capitulari Westmonasteriensi asservatorum abbreviatio: Temporibus regum Ric. I. Johann., Henr. III, Edw. I, Edw. II (1811), London.

Radulfi Nigri Chronica: The Chronicles of Ralph Niger (1851), ed. Robert Anstruther (Publications of the Caxton Society 13), London.

Rôles Gascons (1885-1906), eds. Francisque Michel and Charles Bémont, 4 vols., Paris.

Rotuli curiae regis (1835), ed. Francis Palgrave, 2 vols., London.

Rotuli de dominabus et pueris et puellis de xii comitatibus (1185) (1913), ed. John H. Round (Publications of the Pipe Roll Society 35), London.

Rotuli Hundredorum (1812-1818), 2 vols., London.

Rotuli originalium in curia scaccarii abbreviatio (1805-1810), 2 vols., London.

Rotuli parliamentorum: ut et petitiones in parliament (1767-1777), eds. Joseph Strachey et al., 6 vols., London.

Rotuli Scotiae in turri Londinensi et in domo capitulari Westmonasteriensi asservati (1814-1819), 2 vols., London.

Rotulorum patentium et clausorum cancellariae Hiberniae calendarium (1828), Dublin.

Rotulus cancellarii, vel antigraphum magni rotuli pipae, de tertio anno regni regis Johannis, ed. Joseph Hunter (1833), London.

Rotuli chartarum in turri Londinensi asservati (1837), ed. Thomas D. Hardy, London.

Rotuli litterarum clausarum in turri Londinensi asservati (1833-1844), ed. Thomas D. Hardy, 2 vols. London.

Rotuli litterarum patentium in turri Londinensi asservati (1835), ed. Thomas D. Hardy, London.

Testa de Nevill sive Liber Feodorum in curia scaccarii: Temp. Hen. III et Edw. I (1807), eds. John Caley, William Ingleworth, Henry Ellis and Thomas H. Horne, London.

The Antient Kalendars and Inventories of the Treasury of His Majesty's Exchequer (1836), ed. Francis Palgrave, 3 vols., London.

The Cartae Antiquae Rolls 1-10 (1939), ed. Lionel Landon (Publications of the Pipe Roll Society, new ser. 17), London.

The Great Roll of the Pipe for the Eighth Year of the Reign of King Henry III (Michaelmas 1224) (2005), ed. Emilie Amt (Publications of the Pipe Roll Society, new ser. 54), London.

The Great Roll of the Pipe for the Thirteenth Year of the Reign of King Henry II, AD 1166-1167 (1899) (Publications of the Pipe Roll Society 11), London.

The Great Roll of the Pipe for the Fourteenth Year of the Reign of King Henry the Third, Michaelmas 1230 (1927), ed. Chalfant Robinson (Publications of the Pipe Roll Society, new ser. 4), Princeton.

The Great Roll of the Pipe for the 26th Year of the Reign of King Henry III, A. D. 1241-1242: Now First Printed from the Original (1918), ed. Henry Lewis Cannon (Yale Historical Publications. Manuscripts and Edited Texts 5/Yale Historical Publications 5), New Haven. 
The Memoranda Roll for the Michaelmas Term of the First Year of the Reign of King John (1199-1200) (1943), ed. Henry G. Richardson (Publications of the Pipe Roll Society, new ser. 21), London.

The Memoranda Roll for the Tenth Year of the Reign of King John (1207-8) (1957), ed. R. Allen Brown (Publications of the Pipe Roll Society, new ser. 31), London.

The Red Book of the Exchequer (1896), ed. Hubert Hall, 3 vols. London.

Walter Map, De Nugis Curialium: Courtiers' Trifles (1983), ed. Montague R. James, revised by Cristopher N. L. Brooke and Roger A. B. Mynors (Oxford Medieval Texts), Oxford.

\section{Bibliography}

Agarde, Arthur/Powell, Thomas (1631), The Repertorie of Records, London.

Ashdown, Richard/Howlett, David R./Latham, Ronald Edward (eds.) (1975-2013), Dictionary of Medieval Latin from British Sources, 17 vols., Oxford.

Ayloffe, Joseph (1772), Calendars of the Ancient Charters etc and of the Welch and Scottish Rolls Now Remaining in the Tower of London [...], London.

Barnes, Patricia M. (1962), “The Anstey Case”, in: Patricia M. Barnes and Cecil F. Slade (eds.), A Medieval Miscellany for Doris Mary Stenton (Pipe Roll Society, new ser. 36), London, 1-23.

Baxter, Stephen (2001), “The Representation of Lordship and Land Tenure in Domesday Book”, in: Elisabeth M. Hallam and David Bates (eds.), Domesday Book, Stroud, 73-102.

Berkhofer, Robert F. (2004), Day of Reckoning: Power and Accountability in Medieval France (The Middle Ages Series), Philadelphia.

Bisson, Thomas N. (1998), Tormented Voices: Power, Crisis, and Humanity in Rural Catalonia, 1140-1200, Cambridge.

Cantwell, John Dennis (1991), The Public Record Office 1838-1958, London.

Carpenter, David A. (2004), “The English Royal Chancery in the Thirteenth Century”, in: Adrian Jobson (ed.), English Government in the Thirteenth Century, Woodbridge, 49-69.

CLR (1916-1964), Calendar of Liberate Rolls Preserved in the Public Record Office. Henry III, 6 vols., London.

CPR (1891-1941), Calendar of Patent Rolls Preserved in the Public Record Office. Edward III, 1327-1377, 16 vols., London.

CPR (1893-1901), Calendar of Patent Rolls Preserved in the Public Record Office. Edward I, 4 vols., London.

Chenard, Gaeël (2017), L'Administration d'Alphonse de Poitiers (1241-1271) (Bibliothèque d'histoire médiévale 18), Paris.

Cheney, Christopher R. (1950), English Bishops' Chanceries 1100-1250 (Publications of the Faculty of Arts of the University of Manchester 3), Manchester.

Chiaudano, Mario (1930), Il più antico rotolo di rendiconti della finanza Sabauda (1257-1259), Casale Monferrato.

Chiaudano, Mario (1933-1938), La Finanza Sabauda nel sec. XIII (Biblioteca della Società Storica Subalpina 131-133), 3 vols., Voghera.

Clanchy, Michael T. (2013³), From Memory to Written Record: England 1066-1307, Chichester.

Conway Davies, James (1957), “The Memoranda Rolls of the Exchequer to 1307”, in: James Conway Davies (ed.), Studies Presented to Sir Hilary Jenkinson, Oxford, 97-154.

Corner, Georg Richard (1864), “Observations on Four Illuminations Representing the Courts of Chancery, King's Bench, Common Pleas and Exchequer”, in: Archaeologia 39 (2), 357-372.

Cox, Jane (ed.), with contributions by Thomas, David/Padfield, Timothy/Judd, Michael (1988), The Nation's Memory: A Pictorial Guide to the Public Record Office, London. 
Crooks, Peter (2013), "Reconstructing the Past: The Case of the Medieval Irish Chancery Rolls", in: Felix M. Larkin and Norma M. Dawson (eds.), Lawyers, the Law and History: Irirsh Legal History Society Discourses and Other Papers, 2005-2009 (Irish Legal History Society), Dublin, 281-309.

Douglas, David Charles (19512), English Scholars, 1660-1730, London.

Dunbabin, Jean (2011), The French in the Kingdom of Sicily, 1266-1305, Cambridge.

Dyer, Christopher (2000), "Work Ethics in the Fourteenth Century", in: James S. Bothwell, Peter J. P. Goldberg and W. Mark Ormrod (eds.), The Problem of Labour in Fourteenth-Century England, Woodbridge, 21-41.

Faith, Rosamond Jane (1984), “The 'Great Rumour' of 1377 and Peasant Ideology”, in: Rodney Howard Hilton and Trevor Henry Ashton (eds.), The English Rising of 1381 (Past and Present Publications), Cambridge, 43-73.

Forrest, Ian (2015), “Power and the People in Thirteenth-Century England”, in: Janet E. Burton, Philip R. Schofield and Björn K. Weiler (eds.), Thirteenth Century England XV: Authority and Resistance in the Age of Magna Carta, Woodbridge, 17-34.

Galbraith, Vivian Hunter (1950), “The Date of the Geld Rolls in Exon Domesday”, in: English Historical Review 65, 1-17.

Galbraith, Vivian Hunter/Tait, James (1950), “Introduction”. In: Herefordshire Domesday, circa 11601170: Reproduced by Collotype from Facsimile Photographs of Balliol College Manuscript 350, eds. Vivian Hunter Galbraith and James Tait (Publications of the Pipe Roll society, new ser. 25), London, $\mathrm{i}-\mathrm{xxxii}$.

Guilleré, Christian/Gaulin, Jean-Louis (1992), “Des rouleaux et des hommes: premières recherches sur les comptes de châtellenies savoyards", in: Études Savoisiennes 1, 51-108.

Guyotjeannin, Oliveri/Potin, Yann (2004), “La fabrique de la perpétuité: Le trésor des chartes et les archives du Royaume (XIII ${ }^{\mathrm{e}} \mathrm{XIX}$ e siècles)”, in: Revue de Synthèse, $5^{\mathrm{e}}$ ser. 125, 15-44.

Hallam, Elisabeth M. (1986), Domesday Book Through Nine Centuries, London.

Hallam, Elizabeth M. (1990), “Nine Centuries of Keeping the Public Records”, in: Geoffrey Howard Martin and Peter Spufford (eds.), The Records of the Nation: The Public Record Office 18381988, The British Record Society, 1888-1988, Woodbridge 1990, 23-42.

Hanworth, Ernest M. R. (1935), "Some Notes on the Office of the Master of the Rolls", in: Cambridge Law Journal 5, 313-331.

Harvey, Sally P. J. (1971), “Domesday and its Predecessors”, in: English Historical Review 86, 753-773.

Harvey, Sally P. J. (2016), “A Deed Without a Name”, in: David Roffe and Katherine S. B. Keats-Rohan (eds.), Domesday Now: New Approaches to the Inquest and the Book, Woodbridge, 277-288.

Hudson, John G. H. (1992), "Administration, Family and Perceptions of the Past in Late Twelfth-Century England: Richard FitzNigel and the Dialogue of the Exchequer", in: Paul Magdalino (ed.), The Perception of the Past in Twelfth-Century Europe, London, 75-98.

Introduction to the Study of the Pipe Rolls (1884) (Pipe Roll Society 3), London.

Jenkinson, Hilary (1949), Guide to the Public Records: Part 1 (Introductory), London.

Jolliffe, John E. A. (1948), “The Chamber and the Castle Treasures under King John”, in: Richard W. Hunt (ed.), Studies in Medieval History Presented to F. M. Powicke, Oxford, 117-142.

Knowles, David M. (1963), “Great Historical Enterprises IV: The Rolls Series”, in: David M. Knowles, Great Historical Enterprises: Problems in Monastic History, Edinburgh [reprint of: Knowles, David M. (1961), “Great Historical Enterprises IV: The Rolls Series”, in: Transactions of the Royal Historical Society, new ser. 11, 137-159].

Kosto, Adam (2016), “Review: Watts, John (2009), The Making of Polities. Europe, 1300-1500, Cambridge”, in: The Medieval Review, 10.1.16, <https://scholarworks.iu.edu/journals/index.php/ tmr/article/view/16952> (last accessed: 31.7.18). 
Lachaud, Frédérique (2010), L'Ethique du pouvoir au Moyen Age: l'office dans la culture politique (Angleterre, vers 1150 - vers 1330), Paris.

Lamont, William Montgomerie (1963), Marginal Prynne, 1600-1669 (Studies in Political History), London.

Lamont, William Montgomerie (1996), Puritanism and Historical Controversy (MacGill-Queen's Studies in the History of Religion 26), Montreal.

Langbein, John H./Lerner Renée Lettow/Smith, Bruce P. (eds.) (2009), History of the Common Law: The Development of Anglo-American Legal Institutions, Austin/New York.

Latham, Ronald E. (1968), Calendar of Memoranda Rolls (Exchequer) .... Michaelmas 1326-Michaelmas 1327, London.

List of Chancery Rolls: Preserved in the Public Record Office (1908) (Public Record Office Lists and Indexes 27), Dublin/London.

Loud, Graham A. (2003), "The Kingdom of Sicily and the Kingdom of England, 1066-1266", in: History 88, 540-567.

Madox, Thomas (1711'), The History and Antiquites of the Exchequer of the Kings of England, London. Madox, Thomas (1769²), The History and Antiquities of the Exchequer of the Kings of England, London. Maitland, Frederic William (1893), Records of the Parliament Holden at Westminster [...] (A. D. 1305) (Rolls Series 98), London.

Mason, John F. A. (1954), "The Date of the Geld Rolls”, in: English Historical Review 69, 283-289.

Maxwell-Lyte, Henry C. (19024), Catalogue of Manuscripts and Other Objects in the Museum of the Public Record Office, London.

Maxwell-Lyte, Henry C. (1920), "Preface”, in: Liber Feodorum: The Book of Fees Commonly Called Testa de Nevill. Reformed from the Earliest MSS. by the Deputy Keeper of the Records, ed. Henry C. Maxwell-Lyte, 3 vols., London 1920-1931, vol.1, iii-xxxviii.

Maxwell-Lyte, Henry C. (1926), Historical Notes on the Use of the Great Seal of England, London.

Mayberry, T. W. (1988), Estate Records of the Bishops of Winchester in the Hampshire Record Office, Winchester.

Moore, John S. (2011), “Redating the 'Cartae Baronum”, in: Archives 36, 1-13.

Mullins, Edward L. C. (1958-1983), Texts and Calendars: An Analytical Guide to Serial Publications (Guides and Handbooks 7, 12), 2 vols., London.

Nortier, Michel (1965), “Le Sort des archives dispersées de la Chambre des Comptes de Paris”, in: Bibliothèque de l'Ecole des Chartes 123, 460-537.

Palmer, Robert C./Palmer, Elspeth K./Jenks, Susanne (s. d.), The Anglo-American Legal Tradition, <http://aalt.law.uh.edu/> (last accessed: 3.8.18).

Pocock, John Greville Agard (19872), The Ancient Constitution and the Feudal Law: A Study of English Historical Thought in the Seventeenth Century, Cambridge.

Poole, Reginald L. (1912), The Exchequer in the Twelfth Century: The 'Ford Lectures' Delivered in the University of Oxford in Michaelmas Term, 1911, Oxford.

Powell, Thomas (1622), Directions for Search of Records Remaining in the Chancerie, Tower, Exchequer, with the Limnes Thereof, London.

Raban, Sandra (2004), A Second Domesday? The Hundred Rolls of 1279-80, Oxford.

Ramsay, James H. (1911), “The Origin of the Name 'Pipe Roll”, in: English Historical Review 26, 329-330.

Richardson, Henry G. (1940), “A Twelfth Century Anglo-Norman Charter”, Bulletin of the John Rylands Library Manchester 24, 168-172.

Roffe, David (2016), “McLuhan Meets the Master: Scribal Devices in Great Domesday Book”, in: David Roffe and Katherine S. B. Keats-Rohan (eds.), Domesday Now: New Approaches to the Inquest and the Book, Woodbridge, 81-108.

Round, John Horace (1898), Studies on the Red Book of the Exchequer, London. 
Round, John Horace (19093), Feudal England: Historical Studies on the XIIth and XIIIth Centuries, London.

Rouse, Richard H./Rouse, Mary A. (1974), "The Verbal Concordance to the Scriptures”, in: Archivum Fratrum Praedicatorum 44, 5-30.

Rumble, Alexander R. (1991), “A Domesday Postscript and the Earliest Surviving Pipe Roll”, in: Ian N. Wood and Niels. Lund (eds.), People and Places in Northern Europe, 500-1600: Essays in Honour of Peter Hayes Sawyer, Woodbridge, 123-130.

Sabapathy, John (2014), Officers and Accountability in Medieval England, 1170-1300, Oxford.

Sainty, John C. (1993), The Judges of England 1272-1990: A List of Judges of the Superior Courts

(Selden Society. Supplementary Ser. 10), London.

Santamaria, Jean-Baptiste (2012), La Chambre des comptes de Lille de 1386 à 1419, Turnhout.

Sharpe, Kevin (1979), Sir Robert Cotton, 1586-1631: History and Politics in Early Modern England (Oxford Historical Monographs), Oxford.

Shenton, Caroline (2012), The Day Parliament Burned Down, Oxford.

Sivery, Gérard (1978), "L'influence des techniques comptables italiennes dans les comptabilités administratives de l'Europe du Nord-Ouest vers 1300", in: Luigi Da Rosa (ed.), Studi in memoria di Federigo Melis, 5 vols., Naples, vol.1, 543-552.

Stenton, Doris Mary (1952), “The Pipe Rolls and the Historians, 1600-1883”, in: Cambridge Historical Journal 10 (3), 271-292.

Styles, Philip (1956), “Politics and Historical Research in the Early Seventeenth Century”, in: Levi Fox (ed.), English Historical Scholarship in the Sixteenth and Seventeenth Centuries (Dugdale Society. Publications), Oxford, 49-72.

Suggett, Helen (1942-1943), "An Anglo-Norman Return to the Inquest of Sheriffs”, in: Bulletin of the John Rylands Library Manchester 27, 179-181.

Summerson, Henry (s. d.), “The 1215 Magna Carta: Clause 40, Academic Commentary”, in: The Magna Carta Project, <http://magnacarta.cmp.uea.ac.uk/read/magna_carta_1215/Clause_40/aca〉 (last accessed: 31.7.18).

Tanner, Thomas $\left(1744^{2}\right)$, Notitia Monastica: An Account of All the Abbies, Priories, and Houses of Friers, Heretofore in England and Wales; and also of All the Colleges and Hospitals Founded Before A. D. MDXL, London.

Tate, James (1924), “A New Fragment of the Inquest of Sheriffs (1170)", in: English Historical Review $39,80-83$.

Taylor, Alice (2016), The Shape of the State in Medieval Scotland, 1124-1290 (Oxford Studies in Medieval European History), Oxford.

Taylor, Alice (2017), “Recalling Anglo-Scottish Relations in 1291: Historical Knowledge, Monastic Memory and the Edwardian Inquests", in: Andrew Spencer and Carl Watkins (eds.), Thirteenth Century England XVI: Proceedings of the Cambridge Conference, 2015, Woodbridge, 173-206.

Thomson, John Maitland (1922), The Public Records of Scotland, Glasgow.

Todeschini, G. (2002), Il mercanti e il templo: la società Cristiana e il circolo virtuoso della ricchezza fra Medioevo ed Età Moderna (Collana di storia dell'economia e del credito 11), Bologna.

Vincent, Nicholas (2004), "Why 1199? Bureaucracy and Enrolment under John and his Contemporaries", in: Adrian Jobson (ed.), English Government in the Thirteenth Century, Woodbridge, 17-48.

Vincent, Nicholas (2007), “The Court of Henry II”, in: Christopher Harper Bill and Nicholas Vincent (eds.), Henry II. New Interpretations, Woodbridge, 278-334.

Vincent, Nicholas (2009), “Introduction: The Record of 1204”, in: Nicholas Vincent (ed.), Records, Administration and Aristocratic Society in the Anglo-Norman Realm. Papers Commemorating the 800th Anniversary of King John's Loss of Normandy, Woodbridge, xiii-xx. 
Vincent, Nicholas (2017), “The Kings of England and their Accounting Procedures (1100-1300). Theory and Practice", in: Thierry Pécout (ed.), De l'autel à l'écritoire genèse des comptabilités princières en occident (XII - XIVe siècle) (Romanité et modernité du droit), Paris, 107-130.

Vincent, Nicholas (forthcoming a), "Rouleaux ou registres? Le choix et l'utilisation des enregistrements à la chancellerie Plantagenêt (XII $-\mathrm{XIII}$ siécle)", in: Olivier Guyotjeannin et al. (eds.), L'Art du registre à la chancellerie du roi de France, Paris

Vincent, Nicholas (forthcoming b), "Royal Diplomatic and the Shape of the Medieval English State, 1066-1300”, in: Alice Taylor (ed.), Identifying Governmental Forms in Europe, c. 1100-c. 1300, Amsterdam.

Warren, Wilfred L. (1984), "The Myth of Anglo-Norman Administrative Efficiency”, in: Transactions of the Royal Historical Society, 5th ser. 34, 113-132.

Watts, John (2009), The Making of Polities: Europe, 1300-1500 (Cambridge Medieval Textbooks), Cambridge.

Wernham, Richard Bruce (1956), "The Public Records in the Sixteenth and Seventeenth Centuries", in: Levi Fox (ed.), English Historical Scholarship in the Sixteenth and Seventeenth Centuries (Dugdale Society. Publications), Oxford, 11-30.

Wiles, Kate/Gallagher, Robert (forthcoming), "The Endorsement Practices of Anglo-Saxon England", in: The Languages of Early Medieval Charters.

Wilkinson, Bertie (1929), The Chancery under Edward III (Publications of the University of Manchester 189; Historical Series 51), Manchester.

Wright, Thomas (1839), The Political Songs of England (Camden Society 6), London.

\section{Websites}

"Court of Common Pleas and King’s Bench, and Justices Itinerant: Early Plea and Essoin Rolls", in: The National Archives' Catalogue, <http://discovery.nationalarchives.gov.uk/details/r/C10030> (last accessed: 5.8.18).

"Exchequer: King's Remembrancer: Memoranda Rolls and Enrolment Books", in: The National Archives' Catalogue, <http://discovery.nationalarchives.gov.uk/details/r/C6604> (last accessed: 31.7.18).

“Four Illuminated Manuscripts”, in: Inner Temple Library, <https://www.innertemplelibrary.org.uk/ collections/manuscript-collection/four-illuminated-manuscripts/> (last accessed: 3.8.18).

“Magna Carta 2015, translated and with a Commentary by Henry Summerson”, in: The Magna Carta Project, <http://magnacarta.cmp.uea.ac.uk/read/magna_carta_1215> (last accessed: 6.8.18).

“Medieval Source Material on the Internet: Pipe Rolls", in: Some Notes on Medieval English Genealogy, <http://www.medievalgenealogy.org.uk/sources/pipe.shtml> (last accessed: 5.8.18).

"Structure and Form of the Irish Chancery Rolls", in: CIRCLE. A Calendar of Irish Chancery Letters c. 1244-1509, <https://chancery.tcd.ie/content/irish-chancery-rolls\#structure-and-form-of-theirish-chancery-rolls $>$ (last accessed: 31.7 .18 ). 


\section{Photo credits}

Fig. 1: Thomas Madox (17111), The History and Antiquites of the Exchequer of the Kings of England, London, 63. Copyright Molly Tyson.

Fig. 2, 4-6, 8: By permission of The National Archives Kew.

Fig. 3: By permission of The Masters of the Bench of the Inner Temple.

Fig. 7: Sailko, Wikimedia Commons, licensed under CC BY-SA 3.0 (http://creativecommons.org/ licenses/by-sa/3.0/). 